SF 67

. A2 D3

Copy 1

\title{
LIVE STOCK
}

A PRODUCER OF WEALTH

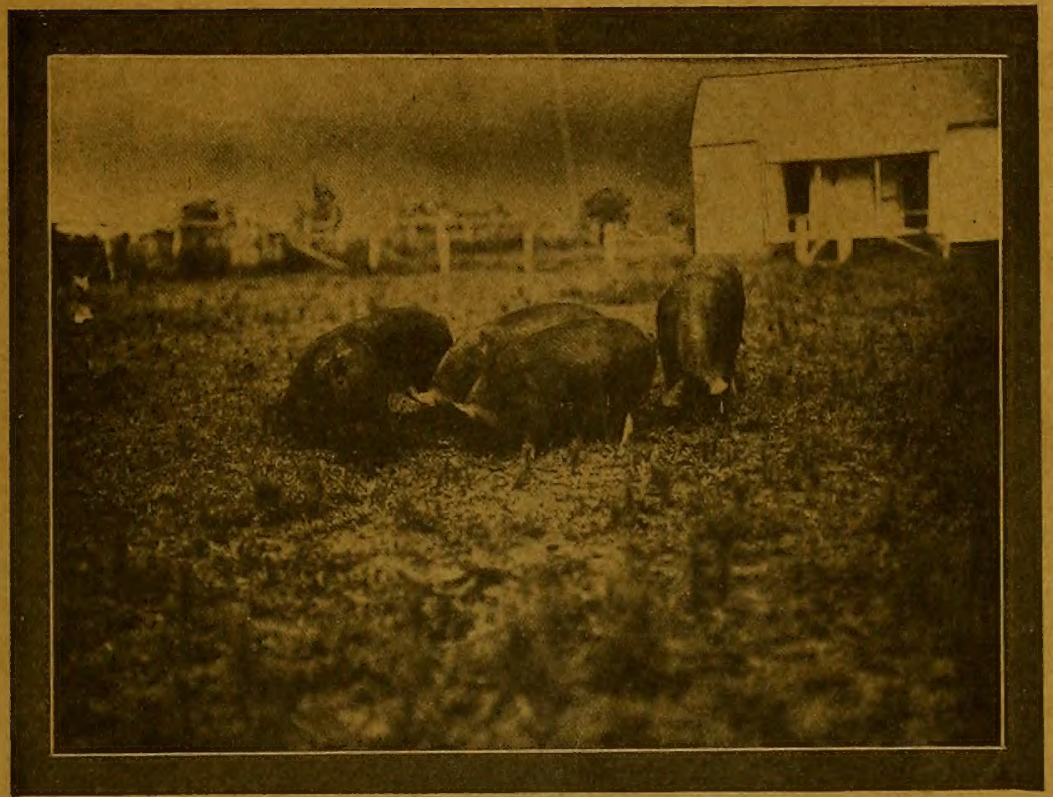

BERKSHIRE HOGS

Compiled by

CLARENDON DAVIS, PRESIDENT

HUNTSVILLE BANK \& TRUST CO.

Huntsville, Ala. 



\section{LIVE STOCK}

\section{A PRODUCER OF WEALTH}

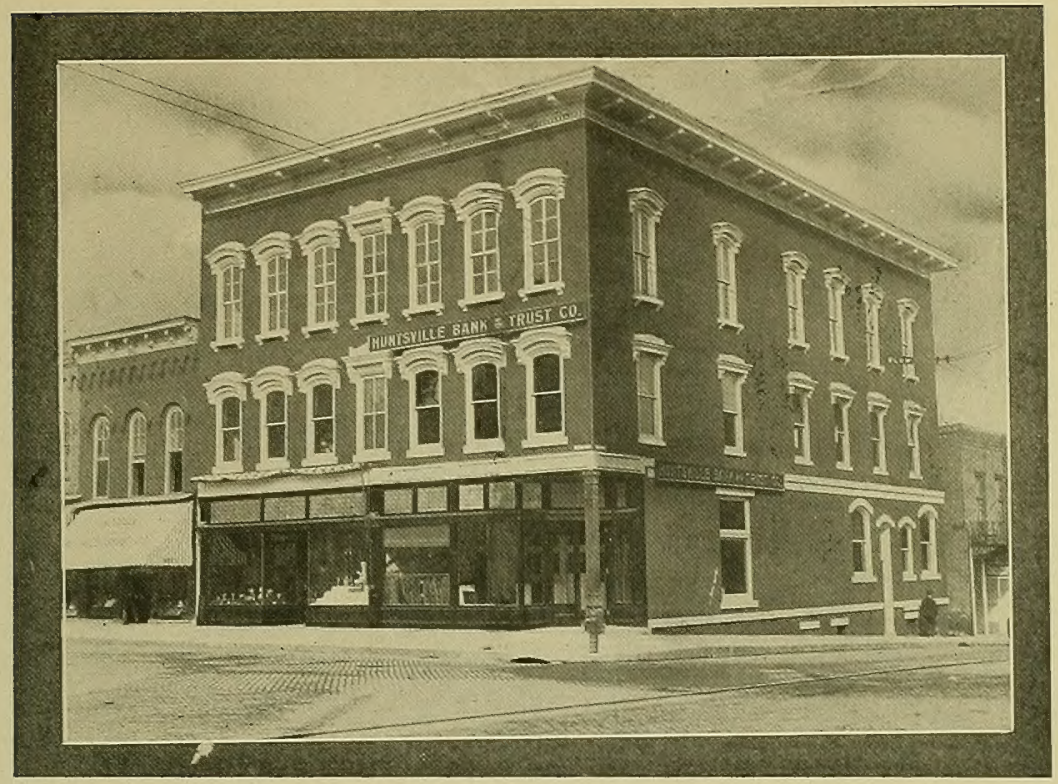

HUNTSVILLE BANK \& TRUST CO.

Compiled by

Clarendon Davis, President

Huntsville Bank \& Trust Co.

Huntsville, Ala.

Copyrighted, 1913, by Clarendon Davis

Nashville, Tenn. MCQUIDDY PRINTING Co.

$$
1913
$$




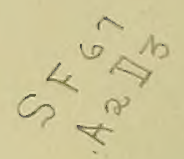

\section{THE TENNESSEE VALLEY}

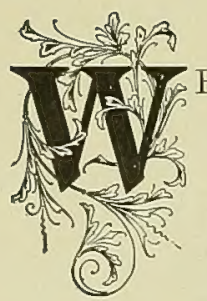

HEN God created the Tennessee Valley, he smiled upon it. He made a beautiful undulating prairie and dropped cloud-tapping mountains here and there, forming fertile valleys, traced with sparkling streams of pure water; and over all he threw a mantle of stately forests and nutritious grasses.

Nature made this country a "farmer's paradise." Had man done his part, what a beautiful panorama would now be presented to the eye of man! A country clothed in its original fertility; its valleys flecked here and there with pretty homes, amidst fields of cotton and cereals; its pastures extending over the rolling lands and far up the mountain sides; the cattle, with their well-filled paunches, quietly resting under the shade of the trees, would be a picture of peace and plenty nestling over all like a benediction.

What man has destroyed must be rebuilt, and to those farmers and business men who will join us in our effort to restore this country to its original beauty and worth this little book is respectfully dedicated.

HUNTSVILLE BANK AND TRUST COMPANY. 


\section{THE BANKER AND THE FARMER}

I

$T$ has only been in very recent years that a farmer in the South could borrow from a bank. His merchant was his banker, or else he went to a money lender for his loans.

In fact, under the old banking régime the average borrower, be he farmer or merchant, went to the banks to borrow under urgent necessity, for he dreaded the visit to that little partitioned-off cor-

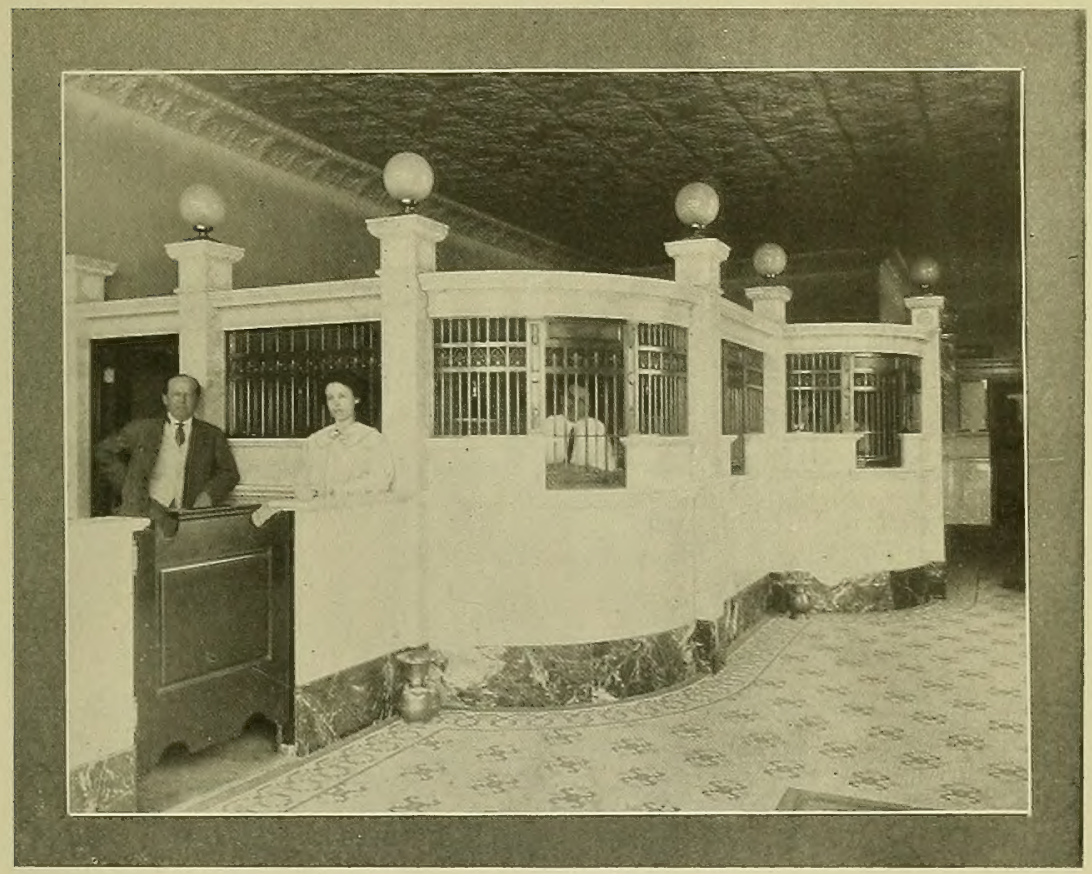

Huntsville Bank and Trust Company

ner which held the cashier's desk and an extra chair. It was like walking into the ammoniated chamber of an ice factory to get relief from the cold world. Your blood was chilled to the freezing: point by the thought of the great and generous favor you were: about to ask for. You went there asking for a favor; and as you dangled your hat in your hand or wiped cold beads of perspiration 
from your brow, you gladly welcomed a "Yes" or "No" for the relief it brought from that awful suspense. You felt as grateful for the "No" as you expected to feel for the "Yes." You made a break for the door like a loose mule out of the barn on a frosty morning, and put distance between you and that financial iceberg. The farther you retreated, the warmer the air seemed to feel; and as you turned to get one last look at that mystery of mysteries, you wondered at your courage that led you to face it.

Now be honest. Did you ever have that experience? Or was it you never got up the necessary courage?

The Huntsville Bank and Trust Company realizes that its interests and the interests of the farmer are identical. They cannot be separated, and the bank feels that any help it can extend to the farmer will more than be repaid in an increase of business, besides the satisfaction in knowing that it is an institution that is a benefit to the community in which it is established. Banks are established for the benefit and the accommodation of those who wish to take advantage of the opportunities their facilities offer, and not for the profits or salaries of those who run them. The first duty of a bank is to safeguard the interest of its customers, regardless of the profits derived therefrom. We want the farmers' banking business, and promise them fair and courteous treatment and all accommodations consistent with prudent banking. We extend to you an invitation to become a customer. It matters not how small, your account will be welcome.

We want you to feel that you are always welcome to bring your financial troubles to us, and that we will always try to help you. Make this bank your headquarters and meeting place while in town. Write your letters or transact any private business. We will assist you in figuring out your sales tickets for the sale of your farm products or interest on your notes; in fact, we want you to fully realize that we run this bank for your accommodation and information. It matters not whether you are making a deposit, asking for a loan, having us figure up a cotton ticket, or want a bulletin on some special farm product or to place your valuable papers in our vault for safe-keeping, we will try to make you feel that you have done us a favor.

We have spent years in studying and practicing farm methods 
best adapted to our soil and climate. We have spent years experimenting, and have kept an accurate account on the money returns. We are familiar with the needs and conditions of the farmer. We have not only made a study of successful farming in this county, but in other counties of this State and some counties in other States having the same soil and climatic conditions.

We have gathered a fund of information that is yours for the asking. If we cannot help you, we wiil bring some one into the county who can, as we have been assured of the hearty coöperation of the United States and State Departments of Agriculture, State Experiment Station, and the Southern and Nashville, Chattanooga and St. Louis Railways, with their armies of experts.

\section{CLARENDON DAVIS.}

\section{THE BUSINESS FARIMER}

I

$S$ the farmer prospers, so will every other line of business prosper. He is a wealth producer, and upon his shoulders rests the financial prosperity of the State. If he fails, the State fails. Then it becomes the duty of every citizen, every commercial enterprise, to encourage and assist him in his efforts for better credits, better farms, better stock, better buildings, roads, schoolhouses, and churches, that he and his family may enjoy better social conditions and enjoy the pleasures and some of the luxuries of this life.

Good roads and the telephone and the rural mail have put the farmer in touch with the outside world, and those who are ambitious to rise above the common level have become thinkers and students and are rapidly making themselves recognized as business men.

The gap separating the wide-awake business farmer from the slipshod, fertility-destroying individual who plants in the moon and depends upon nature for the profit is broadening every day. The business farmer is advancing with the rest of the world, while his unfortunate neighbor who farms as did his ancestors is drifting down the stream of adversity.

The common conception of the business side of the farmer is

Page 5 


\section{I VE STOCK}
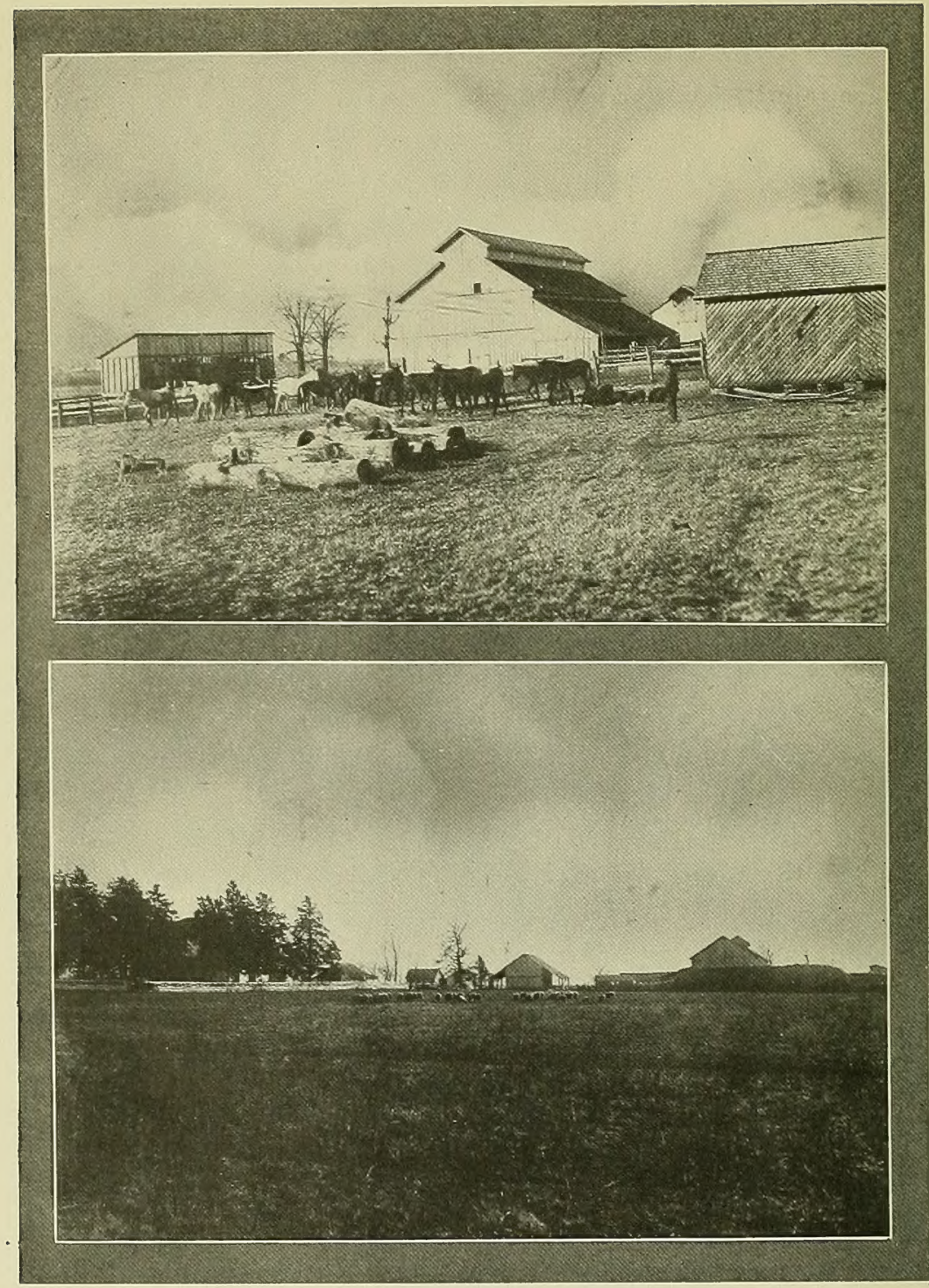

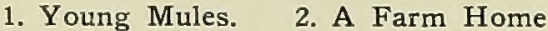

to sow, reap, haul the products to town, sell them for what they bring, pay your debts, and go back home to start all over again.

The farmer of to-day must be a business man, contrary to the common conception of what it takes to be a farmer. 
The success of a business is measured by results. The success of a farmer is not measured by his efforts, but by the results of his efforts. Results are what count. The crop result of an acre determines the value of the soil. If by business methods in cultivation and business methods in placing the products on the market we are enabled to double the income from our land, we more than double the value of our lands.

To increase the productiveness of the land requires careful thought and study. One hour of rest plus one hour of thoughtful consideration of a definite plan is equal to four hours of scattering manure or sixteen hours between the handles of a bull-tongue plow. The productiveness of our land, measured by the cost of production, determines the degree of success of farming as a business venture. Productiveness of the soil is not determined by the muscular effort expended in its tillage, even though supplemented with commercial fertilizers. Many a farmer has confused commercial fertilizers with brains. He has tried to substitute commercial fertilizers for brains. He has tried to substitute the offal and carcass of the $o x$ and the remains of prehistoric animals for the gray matter lying dormant in his head.

There is more plant food in one ounce of brain than in a car load of commercial fertilizers when it comes to a permanent growth of productiveness.

Commercial fertilizers are a Godsend when properly used and a curse when used to stimulate the land for present needs. Stimulation to-day lessens the productiveness of to-morrow. We cannot lessen the cost of production if we lessen productiveness.

The greatest problem confronting the Southern farmer is that of productiveness. The greatest business opportunity in all this country lies under our feet. It is the restoration of our unproductive lands.

The business opportunity of the South is the restoration of the unproductive soils. It is more profitable to build up unproductive soils that were once good than it is to farm the average productive ones. It is provoking to hear a stranger, let alone one of our citizens, speak of the worn-out lands of the South. There is no wornout land in the South. If it was once good, it is still good. It may be unproductive, made so by unbusinesslike methods. We have 


\section{I VE STOCK}

sapped its life. We have changed its mechanical condition, and now it is a dead soil, but one that can easily be brought back to a high State of productiveness.

It is a common failing to neglect the opportunities at our feet because they have become commonplace by long association. We long for the fleshpots of the North or seek the golden opportunities

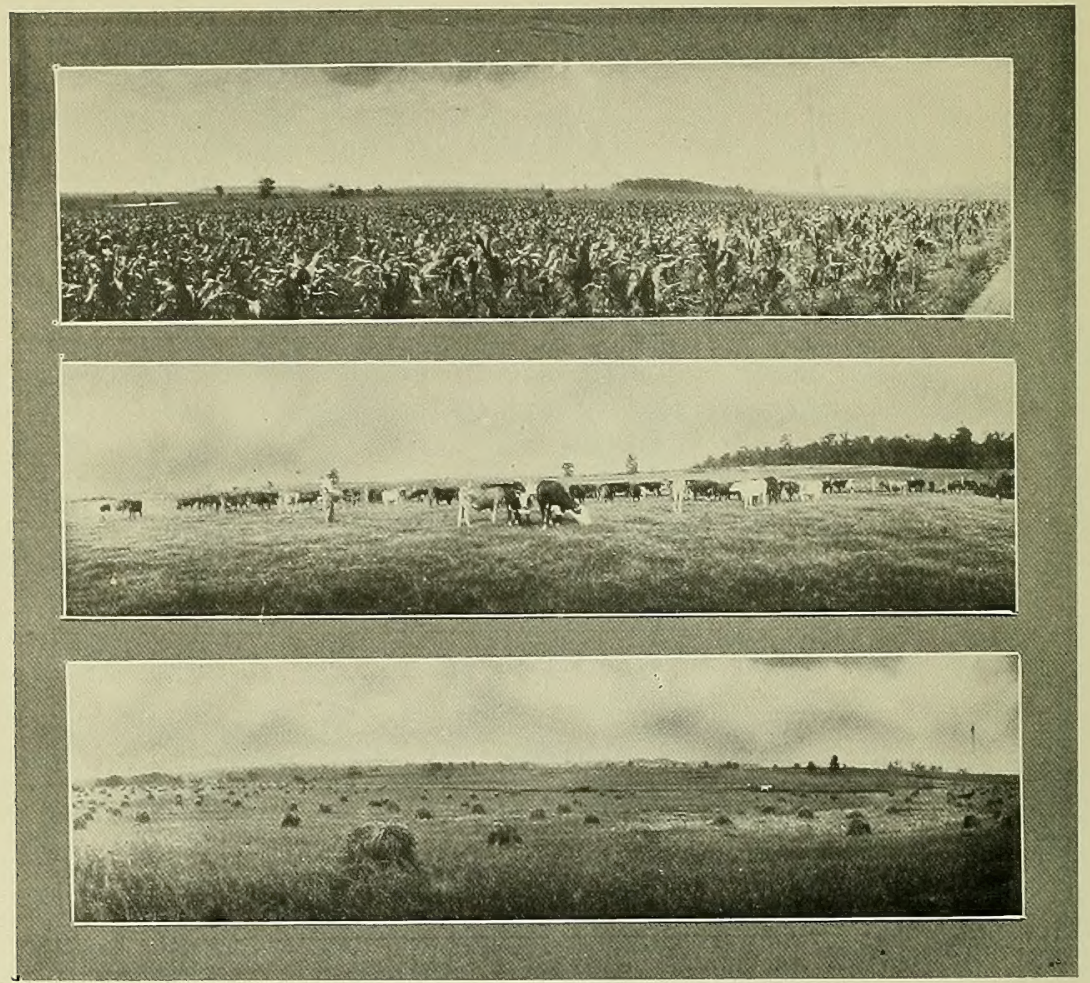

1. Corn Field of Clarendon Davis. 2. Clarendon Davis' Cattle on Bermuda 3. Wheat Field of Madison County

of the West, and are led away by a mirage of plenty to lands where adverse conditions excite our inert energy to conquer; and we build prosperous towns, cities, and communities by the brain and muscle that justly belong to the land of our birth.

I used to think there were some of our lands that Providence made in order to keep from being a hole in the ground, or just to 
hold better portions together. I now believe all lands, of whatever character, are intended to be utilized for some good purpose.

In the northwest corner of my home county is a strip of land known as the "barrens" that a few years ago was considered worthless as farm land and could have been bought for $\$ 2.50$ per acre. It is an extension of the Highland Rim of Tennessee. As the Farm Demonstrator of my county, I secured the coöperation of a gentleman sixty-five years of age to farm twenty acres of his land by the improved methods as outlined by the Department of Agriculture, with the results that have astonished the whole country. This gentleman has proved that the Highland Rim soil is as good as the rest of the world. He raised oats to the value of $\$ 75$; hay, $\$ 150$; corn average, forty-five bushels to the acre, $\$ 276.25$; peas grown between the corn rows, $\$ 35$; one-half bale of cotton at $\$ 12.65$; cotton seed, $\$ 16$ a ton. The total was $\$ 850$. After deducting the cost of labor and fertilizer of $\$ 125$, we have a net profit of $\$ 725$, or $\$ 36.25$ net per acre. In this case it was not the land; it was the man. It was an illustration where brains were used. It is an example for the rest of the farmers of the South. What one man can do all can do, if the use of the same care and judgment is employed.

The average income over and above cost of taxes, insurance, labor, and general farm expense of the six and one-half million farms of this country is $\$ 700$, or less than $\$ 2$ a day. Just think of it- $\$ 2$ ! Is this enough for the average farmer? Is this enough for him to meet his church dues, buy his clothing, his carriage, or his automobile? The mechanic makes more than this, and no capital invested other than his brains. Two dollars a day profit is not enough for the average farmer, and to increase this we must increase productiveness and lessen cost of production and use more businesslike methods in marketing the crops.

It is a simple matter to increase the producing capacity of our soil, if we will conform to a few simple rules laid down by nature. :Take, for instance, one of the old, unproductive fields of our farm. If we would let it alone, Nature would restore it; but, with our as-

Six months' work on the farm will not produce six months' income.

Page 9 
sistance, she will do in five years what it would take her twenty years to do alone.

The first essential is to add humus to the soil by turning under some vegetable matter, it matters not what. Plant anything that will give the greatest growth, and stimulate to the rankest growth by the use of commercial fertilizers; and when it has reached its full maturity, turn it under. Then if the soil is deficient in lime, which is the case with the majority of the soils of the South, add the ground rock and harrow it in. Few realize the great value of the sorghum plant as a source of humus. This plant will make

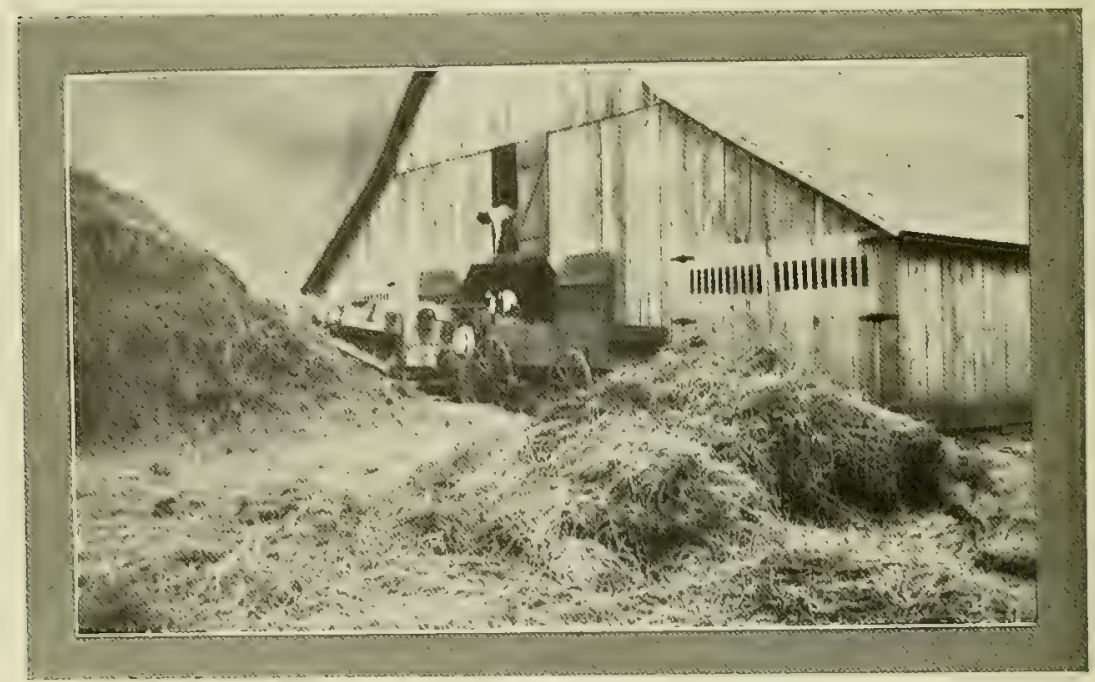

Thrashing

more growth on thin soil than any other. It is said to be very exhausting to the soil, and it is if we remove the crop; but in our soil building we must return all of the growth from our first crops. If the growth is turned under in the fall and rye sown to be turned under in the late spring, we will be in shape to sow the land in clover or peas. Land so treated and sown to clover or peas, with liberal applications of phosphates and potash, will almost insure a good crop if the rainfall is sufficient.

When we can grow heavy crops of clover and peas, even with liberal use of commercial fertilizers, the soil will increase in fertility, if we keep in mind that we must add humus. 


\section{LIVE STOCK}

It is said that $\$ 250,000,000$ is burnt up every year on the farms of this country. That means $\$ 41$ of vegetable matter is burnt up every year, on an average, to every farm. A soil builder will never burn up grass, stubble, or even weeds. He knows too well the humus-forming value of these.

Humus first, then lime, then nitrogen, is the keynote. Humus is placed first because it is the "soul of the soil." Without it we can never become soil builders. It makes the soil porous, retentive of heat and moisture, and tends by chemical action to liberate the mineral plant foods. In short, it makes a dead soil a live soil.

You cannot make money on poor land. Then build it up by persistently feeding it with vegetable matter, be it by plowing it under or feeding the products to stock and returning the manure. The more you return to the soil, the more it will give back to you, with a big percentage of profit of its use. This is business.

To be a business farmer does not necessarily mean the possession of broad acres and unlimited capital, but it does mean that he is a builder, a constructor, one who is not planting and reaping without one thought of to-morrow, but one who farms with a view of increased fertility, one who builds up his acres in order to increase the value of his possessions and the value of citizenship.

Too many farmers aim to buy more land, and thus spread their limited means over greater acreage, when they have failed to show their ability to manage what they already possess. There is not one farmer in the South who is getting all from his land that it is able to produce. When a farmer shows his ability to manage successfully that which he now owns, it is no trouble for him to secure the means to make improvements or increase his holdings.

He has shown what financial credit he is entitled to, and it is extended before the asking. It is true in time past that even the progressive farmer has been handicapped by the lack of ready money which his credit entitled him to, and then at such exorbitant rates of interest that it has been the means of retarding the Southern farmers' advancement. In fact, farming is the only business that could have existed, let alone thrive, with such usurious interest they have been compelled to pay.

The business farmer is no longer handicapped by this condition of affairs. The lawyer, the doctor, the merchant, the banker, have 


\section{LIVE STOCK}

been made to feel that all their success depends upon the success of the tiller of the soil; and being men of business, they see and are ready to extend to the farmer.every aid and facility that will better his condition. Some of the bankers of the South have just realized what agricultural advancement means to them. They are making a close study of the farmer and his needs, and are extending the helping hand that has so long been denied the farmer. They are putting their heads together to devise some means by which they can extend to the farmer the long-time loans so essential for constructive purposes. In other words, they see the necessity

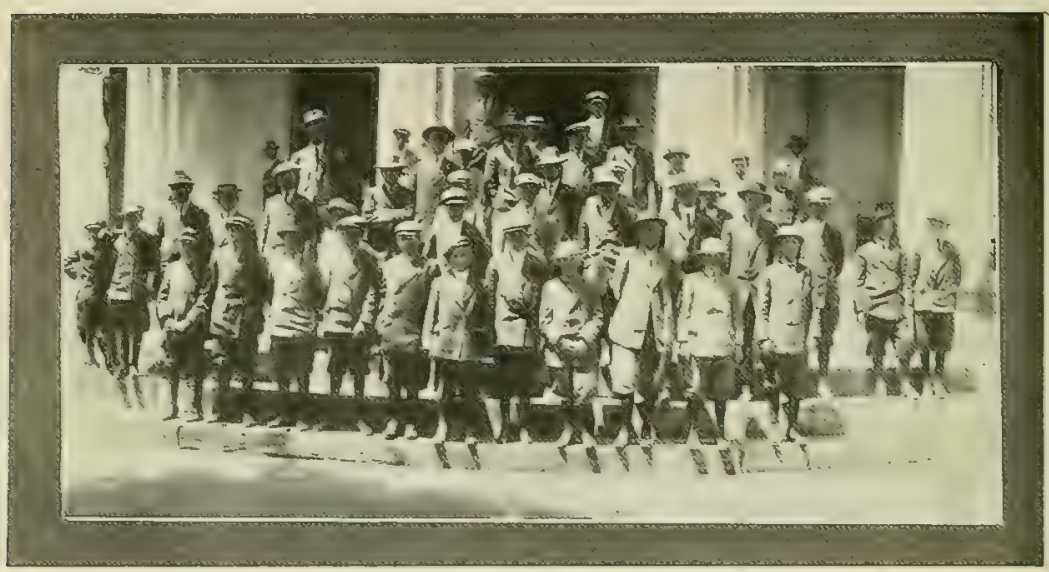

Boys' Corn Club

of long-time loans to the farmer that are so readily available to the railroad and other like corporations. The national and State banking laws prohibit this, but this need not discourage the ambitious farmer. He cannot afford to wait for the legislative bodies to make laws favoring him. His banker now knows the value of his collateral, and knows that the business of the business farmer is most desirable. You have but to show the banker that you are a business man, however small, and he is ready to help you. Not you who are satisfied with your present slipshod, soil-robbing, shiftless, unprofitable methods; not you who are content to work during the sunshiny days, six months of the year, and then sit down

Light plows mean light crops. 
and eat up the products of your six months' labor; but the help is for you who aim to climb higher each year, you who are building up your soil's fertility for the needs of to-morrow, you who are not content to be dictated to by a speculative market that by the tick of the wire can wipe out the profits of a year's work. It is to you who live at home and are industrious and honest.

Credit does not always depend upon what you may possess of these worldly goods, but more upon what you are and your standard as a citizen.

CLARENDON DAVIS.

\section{TENNESSEE VALLEY A LIVE-STOCK COUNTRY}

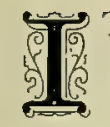

T has been predicted by those who are in a position to know that the northern parts of Georgia, Alabama, Nississippi, and parts of Kentucky and Tennessee will be the center of the beef-producing section of this country. In fact, the future must look to this section for its meat supply. Beef has been produced cheaper in the South than anywhere else in the world.

Live stock on the farm is the greatest factor in restoring and maintaining lost fertility. Cattle, hogs, and sheep are the greatest assets of the farm. The one-crop system reduces fertility; stock raising produces fertility. The one-crop system reduces humus, "the soul of the soil;" stock raising increases the humus. The one-crop system decreases yields; stock raising increases yields. The one-crop system is productive of mortgages; livestock raising prevents the mortgages.

Live-stock raising is the panacea for all the evils of the present system of farming now too common to the South. It is the virus by which we may inoculate ourselves against financial distress that periodically visits the South. The one-crop system as practiced in the South has meant a constant warfare against grass. Grass means live stock, live stock means fertility, fertility means wealth. When you destroy grass, you destroy wealth.

This is a natural grass country; and had our meadows and pastures the same attention that we have given our other crops, this section would have been many times more productive, her surface

Page 13 




\section{Jersey Bull. 2. Draft Stallion}

more pleasing to the eye, and her financial condition of a higher standard.

In fighting grass, we have been fighting Nature's good intentions. No system of farming can hope to be successful that does not as- 


\section{I V E S T OCK}

sist and encourage Nature in her efforts to build up the soil's fertility by growing those crops best adapted to her soil and climate. It only means financial ruin for the farmer and a setback to Nature. Notwithstanding the setback grass has had, it has been able to prove its ability to make good crops and to produce beef, pork, and mutton at a profit that should have led the Southern farmer to recognize its worth.

Grass, with its persistency, is soon to be reinforced in its efforts for a more economical system of farming by the boll weevil. The boll weevil one year with another will destroy twenty per cent of our cotton crop, and this means the wiping out of all profits on a depleted soil. To continue to raise cotton under boll-weevil conditions, and to do so profitably, we must increase and maintain the soil's fertility. To wait until the advent of the boll weevil before making the change would be too late to avoid financial distress. We must begin now to plant grasses, clovers, and raise the stock necessary to consume them and convert them into food for man.

The production of cotton can be made profitable even under bollweevil conditions, but it must be under a condition where we can obtain maximum yields with decreased cost of production, and this is possible only when supplemented by live-stock raising.

Beef shortage is world wide. The United States, once a great beef-producing country, with a large export trade, has sustained a decrease of ninety-two per cent in six years. In 1906 the United States exported 494,000 head, valued at $\$ 38,000,000$. In 1912 she exported 36,000 head, valued at $\$ 3,000,000$. The decrease has been systematically, month by month; and it is predicted that our exports will only be 10,000 head in 1913 . In 1912 we imported 326,000 head, valued at $\$ 5,300,000$. In other words, the United States does not raise enough cattle to feed her own people. This shortage is not only felt in the United States, but is world wide. Australia, once a great cattle-exporting country, has for the past few years suffered from droughts that have depleted her herds and discouraged her ranchmen. Argentina, whom we have been taught was a menace to our export trade, has for three years suffered from droughts and foot and mouth disease, which have made beef-producing conditions unfavorable.

The world must be fed. Where is this to come from? Here is 
the Tennessee Valley, where we have proven our ability to raise beef cheaper than anywhere else. We continue to raise cotton, and have it thrown up to us that the low price is due to a great surplus carried over that the manufacturer could not use. Why continue to raise a surplus of a product when it would be more profitable to raise a product for which the supply is not equal to the demand? Does it not seem more rational to wipe out the great surplus of cotton by devoting less land to its production and

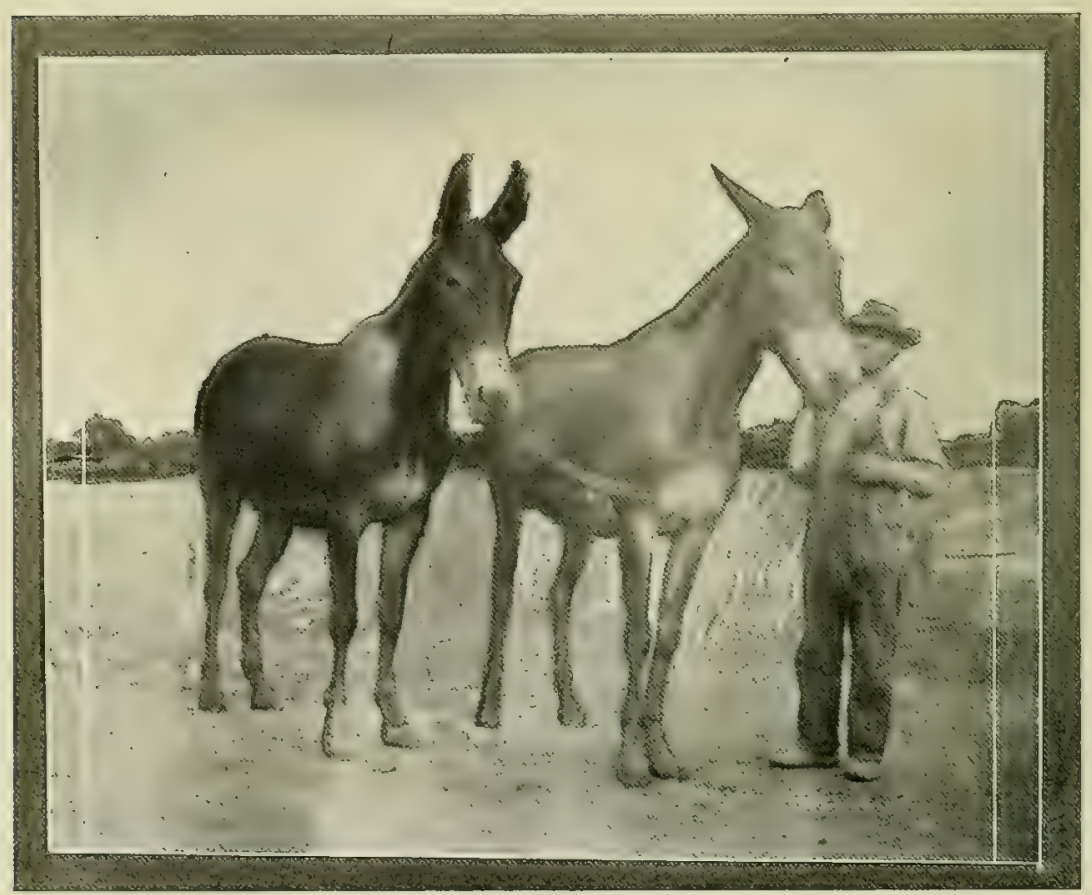

Alabama-Raised Mules

devoting it to the production of beef, for which there is a demand that cannot be filled?

Those who will take advantage of this situation of supply and demand are the ones who will reap the benefit. This opportunity is open to the small farmer, with his four or five cows, as well as the large farmer, with his forty or fifty. We have the foundation and need but the pure-bred beef bull to make the start.

We have been for the last year selling our cows and heifers to 


\section{LIVE STOCK}

Northern buyers at prices that seemed good to us. We have congratulated ourselves on being able to rid our farms of this scrub stuff, and we have had a secret feeling that we got the best of the trade and really pitied the buyer. Men who would come down here from the North and make the fool trades we thought they were making are confined up there in the asylums. Those Northern buyers will, in a year or two, prove their wisdom in purchasing what to us would have been a gold mine if we would have but recognized it in time.

The Farm Demonstration Department or Bureau of Plant Industry has aptly sent out the following warning to the Southern farmers:

"If the Western ranchman can afford to pay Southern farmers good prices for cows, pay the high freight rates to the West, stand the losses which naturally occur during shipping thin cattle such long distances, also bear the losses due to change of climate conditions, and then make money on them, why cannot the Southern farmer, who already owns the cattle as well as the grazing lands, and who needs the manure upon the soils, keep this stock on the farm and secure the increased profits? He can, if he will free his cattle of ticks, increase the efficiency of his pastures by planting mixtures of lespedeza, bur clover, white clover, or perhaps melilotus, alsike clover, and red top over his pasture lands, and by raising more hays and forage crops for wintering his stock and finishing them for market. The surplus cattle can then be fattened by feeding cotton-seed cake on grass, grazing fields of velvet beans, while feeding some concentrate, or they can be finished in the dry lot during the winter months. For winter feeding no roughage has proved more valuable than silage, as the addition of it to a feeding. ration invariably increases the size of the daily gains and reduces the cost of them, thereby making greater profits. The quality and the quantity of silage which can be produced on some of these cheap iands cannot be surpassed by the high-priced lands of the corn belt, whereas the cost of producing it is far less because of the cheap labor."

The farmers of the South are, therefore, urged to discontinue

The one-crop system is productive of crop mortgages. 


\section{LIVE STOCK}

this wholesale shipping of their female cattle to other States, to free the pastures of the cattle tick, and to increase the numbers and quality of their cattle by the use of pure-bred beef bulls. The progeny will not only grow off faster and make larger and better cattle, but will be far more profitable to raise and to feed than are the natives. The soils will be increased in fertility, and manure, which gives such profitable returns when applied to the cotton crop, will put vegetable matter into the soil, thus reducing the

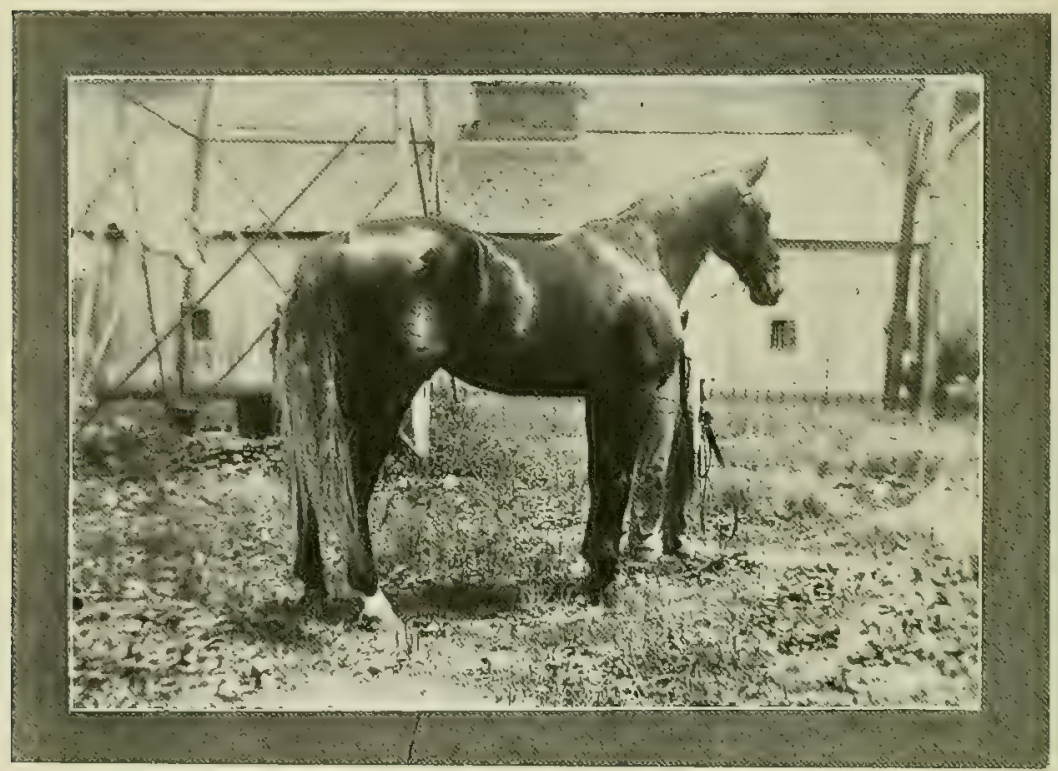

Stallion

amount of commercial fertilizer necessary and increasing the availability of this material. CLARENDON DAVIS.

\section{HOW TO GO INTO LIVE-STOCK FARMING WITH SMALL EXPENSE AND NO RISK}

S

OUTHERN farming is not going to remain as it is. The big fact of our time, so far as agriculture is concerned, is that we are in a period of transition from the old, ruinous, singlecrop system of farming to a sounder and more profitable system 


\section{LiI Y:E S T O C K}

of general and live-stock farming. Many: farmers seem not yet to have realized this fact, but it is a-fact, just the same. "The new spirit of Southern farming, is not so much the spirit of reform as the spirit of revolution, and the revolution is even now taking: place." : It is not only that Southern farmers are practicing better methods, getting better machinery making better crops, but that they are turning away from the false ideas of a system which looked only to the crop to be: sold in the fall and accepting the new ideal of a farming system which looks first of all to the preservation of the soil and links one year with another in an enduring effort to add continually to the farm's productivity and to the profits the farmer shall receive from his work. The South of the future is going to be a land of flocks and herds, of corn fields and silos, of big barns and heavy machinery, of meadows and pastures, and all the things which go with live-stock farming.

This change is not going to come all at once, of course, but very gradually; and it is not going to come at all until farmers realize another big fact: that feeds must come before live stock, and that the grass will not be sowed nor the legumes planted to supply the horses and cattle and hogs and sheep, but that these animals will be grown and fed because of the abundance of feeds and the profits to be had by utilizing them. A system of live-stock farming and the profits that come from live-stock farming are alike impossible without an abundance of feeds. At the very foundation of stock husbandry are grass-clad fields and well-filled haymows; and until these are had, any large development of the live-stock industry will be profitless, if not impossible.

This, then, is the special message I would send the farmers of Northern Alabama. You have a natural live-stock country, one adapted to the growing of the grass and grain crops, which are at the basis of successful stock farming; and with your great advantages of climate over the stock-raising sections of the North; with the cheapest concentrate feed in the world in your own cottonseed meal; with a soil capable, when properly treated, of growing almost any crop; and with the ability to grow two crops every year, there is no reason why the Tennessee Valley should not be come as well known for fine live stock as Wisconsin or Illinois or the Kentucky blue-grass section.

Page 19 


\section{LIVE STOCK}

Nor does it take a whole lot of money to go into live-stock farming. You do not want to "go into" it at all, in fact; you want to "grow into" it-that is, you want to grow more pasture and feed crops, take better care of the stock you have, improve their quality by breeding only to pure-bred sires, and get other and more highly bred animals for breeding purposes just as you are able. Large farmers and small can alike follow this plan, and the reward for each will be both liberal and permanent. E. E. MILLER,

Managing Editor of Progressive Farmer.

\section{PRODUCTIVE SOIL}

ta HEN a soil produces well, we speak of it as being rich, or productive; when it fails to yield good crops, we say it is poor, or worn out. A soil that was originally good may, by continuous cropping and poor methods in cultivation, become unproductive, but it can never be worn out. The humus contents have been destroyed, and it has become a compact, dead soil that may be brought back to a high state of cultivation if we will study its needs and farm it in a way that will supply its needs.

A productive soil is literally a live soil. Every minute particle, so small it cannot be seen with the naked eye, is surrounded by a film of water, which contains millions and millions of microörganisms that are always busy breaking down soil particles, be it bits of rock or plants. They are busy little bodies, working in a congenial home, converting and dissolving compounds into forms available as plant foods. Some are busy making available plant food from materials already in the ground, while others are just as busy adding plant food to the soil. Of the latter class there is the bacteria that enables the legumes to extract nitrogen from the air.

The microörganisms will work for you day and night as long as you provide them with a congenial home. They will take the growth of vegetation or the manure you have turned under and make it a part of the soil. As the cattle and hogs of the farm take the grasses and grain and convert them into food for man, so will 


\section{LIVE STOCK}

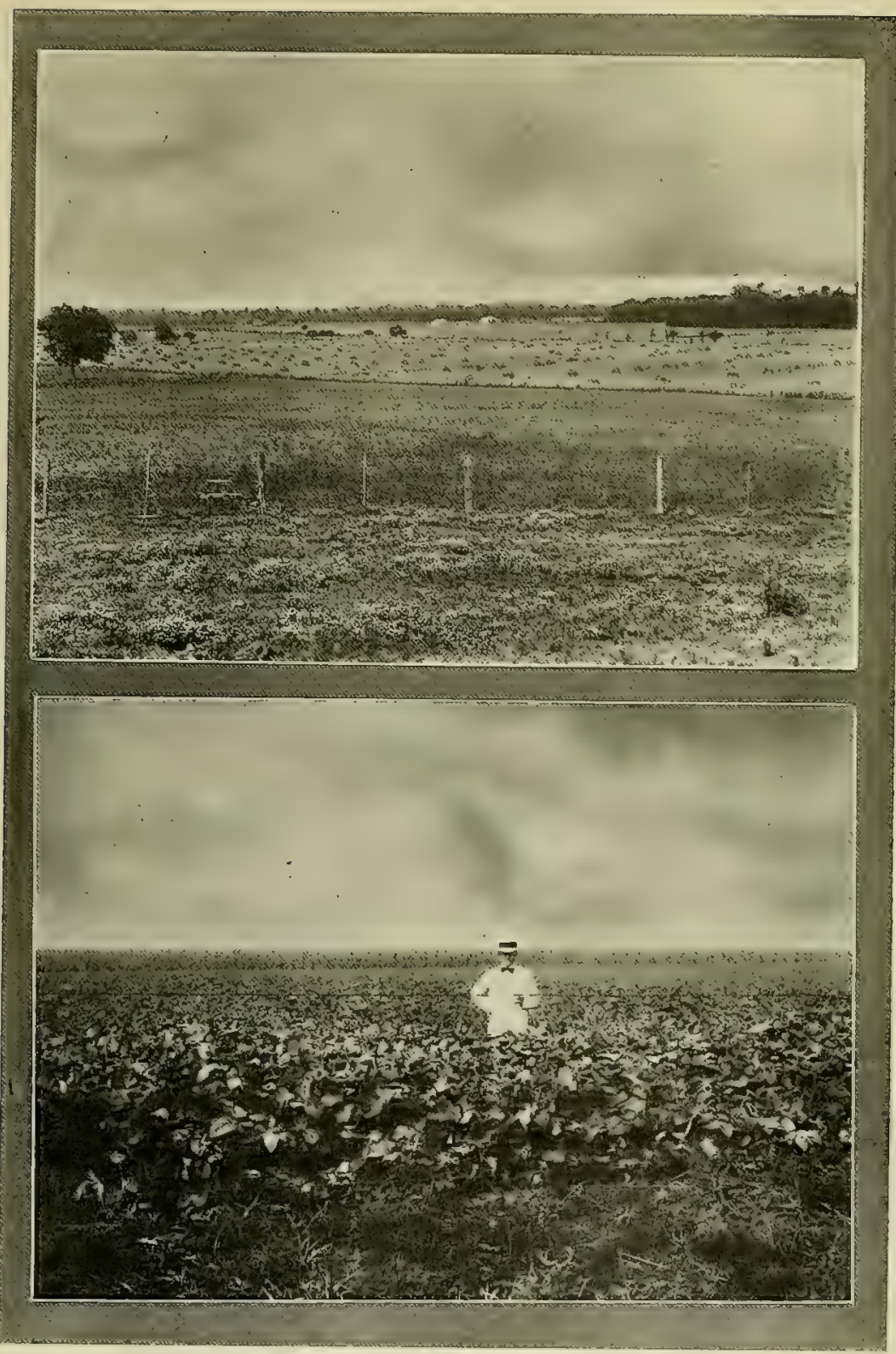

1. Wheat Field of Dan Glessner.

2. Pea Field

Rains and Fertilizers cannot be substituted for Brains and Cultivators.

Page 21 


\section{LIVE STOCK}

the microörganisms take the animal, organic, and mineral matter of the soil and convert them into food for plants.

These beneficial little beings must have plenty of moisture, yet an excess of water is as detrimental to their growth as not enongh water; hence the land must be well drained. They must have plenty of organic matter to live on and plenty of air. In other words, a congenial home or medium in which these microörganisms will live and multiply is a well=drained soil filled with humusforming material, as crops turned under or where applications are made of stable manures.

When crop after crop is taken from the soil and nothing given back, where we pursue the policy of taking that part of the crop that we can sell and burning the balance in order to clean the land, we will soon exhaust the humus contents of the soil-that element that makes the soil retentive of heat and moisture. The soil then becomes compact, the air cannot circulate through it, and it becomes a wet soil in times of excessive rainfall, runs together and dries and bakes quickly when the sun shines hot. Under these conditions, the soil is found to become acid, microörganisms become less active and dwindle in numbers and may be entirely destroyed. The soil then becomes a dead soil.

The humus contents of the soil can be readily increased by the application of barnyard manures or turning under green crops grown for that purpose. No vegetable matter should ever be burned on the farms. All cotton and corn stalks, all grass and weeds should be turned under. No land should be allowed to remain bare during the winter if possible. Get it seeded down to some winter cover crop, this to be plowed under in the spring if land is to be planted. A winter cover crop prevents the leaching of the soil by heavy winter rains. The cover crop takes up the plant food as it becomes available and prevents it from passing off in the soil water.

The loss caused by our winter rains on a soil left bare of all vegetation is estimated by some to be equal to that caused by a crop taken from the soil during the growing season.

The acidity of the soil is easily detected by the use of blue litmus paper obtainable at any drug store. Procure some and take small quantities from different parts of the field; wet these samples thor- 


\section{LIVE STOCK}

oughly and insert a small strip of the litmus paper in each sample. If the paper turns pink, it shows the soil is acid; and this must be corrected by the application of ground limestone, 1,000 to 3,000 pounds to the acre, applied after the ground is broken, as a top dressing, then harrowed in.

When a corn crop of, say, forty bushels is gathered from an acre and the stalks cut and burned, it is equal to taking from the land fertility enough to produce eighty bushels of corn; for there is as much plant food consumed in making the stalk as in making the ear, besides the loss from the beneficial results that would be derived in failing to turn under the humus-forming material.

If you wish to build up your soil, you must always farm it with the idea of making it a congenial home for the microörganisms by turning under organic matter and keeping the land free of acids by the use of lime.

CLARENDON DAVIS.

\section{GRASSES AND PASTURES}

(6) RASSES delight in a frrm seed bed, and one is almost assured of a good stand with his fall or spring seeding if he will sow on a well-prepared seed bed made firm by thorough cultivation.

For spring seeding the ideal conditions, not only for grass, but oats, is found in a corn or cotton field that was well tilled the year previous. Cut the stalks and with disc harrow thoroughly work up the top soil to a depth of two and one-half or three inches; smooth down with spike-tooth harrow and sow the grass seed or sow the oats with the grass seed sown behind the drill. If early in the season, the grass seed should not be covered; but later on in the season when the sun shines hot, it is best to cover very lightly with a brush, a weeder, or a roller.

If the oats are sown very early-say, in January or first of February-the grass seeding can be delayed later until oats are up, running the slant-tooth harrow ahead of the seed sower if plenty of moisture is in the ground; but if it is inclined to be dry, it is best to run the harrow after sowing the grass.

Page 23 


\section{IVE STOCK}

Fall seeding of grass is best sown by itself, sown on a loose top soil and covered with roller. Many have succeeded well and obtained excellent stands of grass sown after the drill on fall-sown grains. As a usual thing, grasses on fall-sown grain are shaded too much to make much of a growth by the time the grain is harvested and is killed by the hot sun in July and August.

Even when sown with the spring seeding of oats, the oats should not be as thick as ordinarily sewn. One bushel to the acre is enough when grass is sown with it.

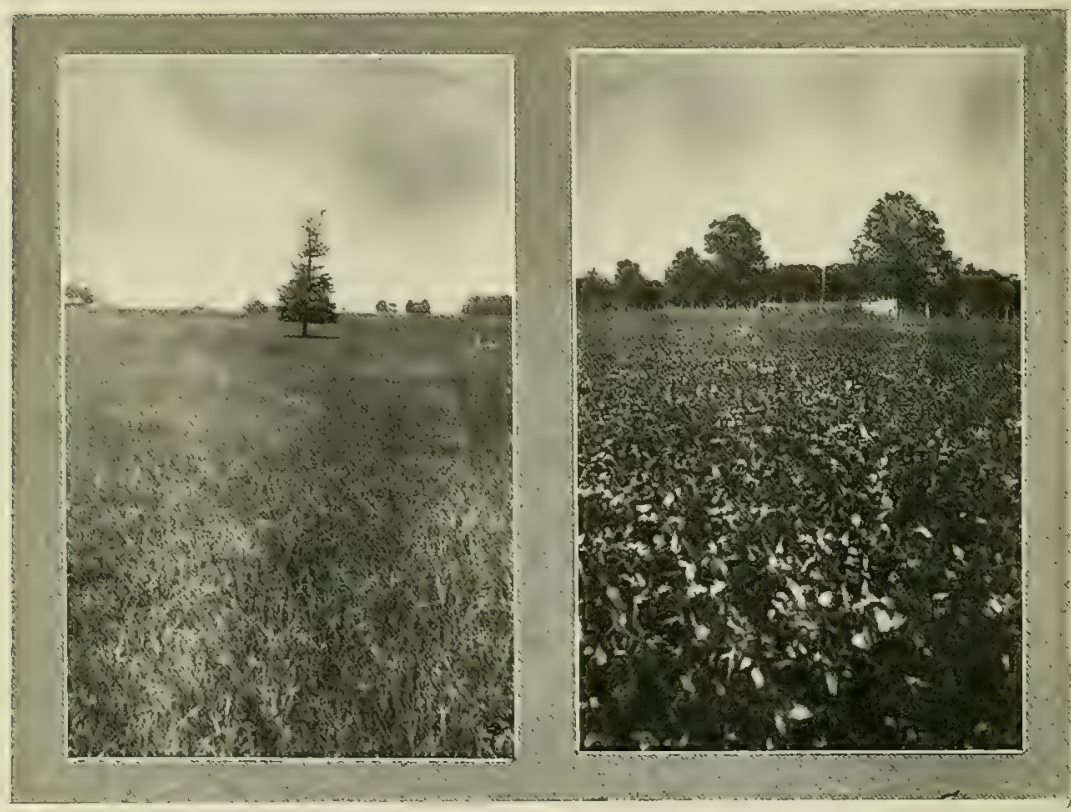

Meadow of D. K. Wall

John Hughes' Pea Field

The grasses that have proven most valuable for the Tennessee Valley, both for hay and pastures, are: Tall meadow oat, red top, timothy, orchard and Bermuda; and all the clovers do well in this section-red, alsike, white, crimson, bur, and Japan clover.

With such a wealth of grasses and clovers that have proven valuable and well adapted to this section, there is little excuse for not having luxuriant pastures, both permanent and rotated, and great barns and ricks of nutritious hay.

Bermuda is the greatest of all known grasses for permanent pas- 
ture. It will furnish more grazing to the acre than any single grass or combination of grasses known to the South.

If small bits of sod are dropped in three-foot furrows, covered and cultivated as you would corn, always covering up as much as possible at each plowing, the grass will cover the ground before fall. When not cultivated, it will in two or three years make a perfect sod.

For rotated pastures of grass, timothy, red top, orchard and tall meadow oat grass, with some red or alsike clover, all sown together, makes an excellent mixture for good loamy lands. For the thin lands, tall meadow oat, red top, Japan, alsike, and a light sprinkling of white clover have been found to give excellent pasture.

Red top and alsike clover will do their best on low, moist soils.

One of the most popular mixtures in the red lands of East Tennessee for pasture and hay is tall oat grass and alsike clover.

No farm, however small, is complete without its permanent pasture of Bermuda; and this should be supplemented with rotated pastures of the tame grasses and the clovers for spring and fall grazing. It is a difficult matter for those on heavy clay lands to have an all-winter pasture, even with the fall-sown grains, due to the puddling of the soil by the stock running on it, there being few days in January and February when ground is dry enough to hold up the stock. It is here that the silo will fill in the gap and virtually permit the raising of stock on pastures the year round.

$$
\text { CLARENDON DAVIS. }
$$

\section{CORN}

(ฮ)

successfully raise corn, we must begin our preparation at least one or two years before planting. No land will produce a profitable corn crop that is not in good mechanical condition, and we cannot get it in a good mechanical condition unless we have humus in the soil. To get humus, we must plow under a crop of clover, peas, or even sorghum and peas in the fall or early spring. Humus makes the soil retentive of heat and mois- 


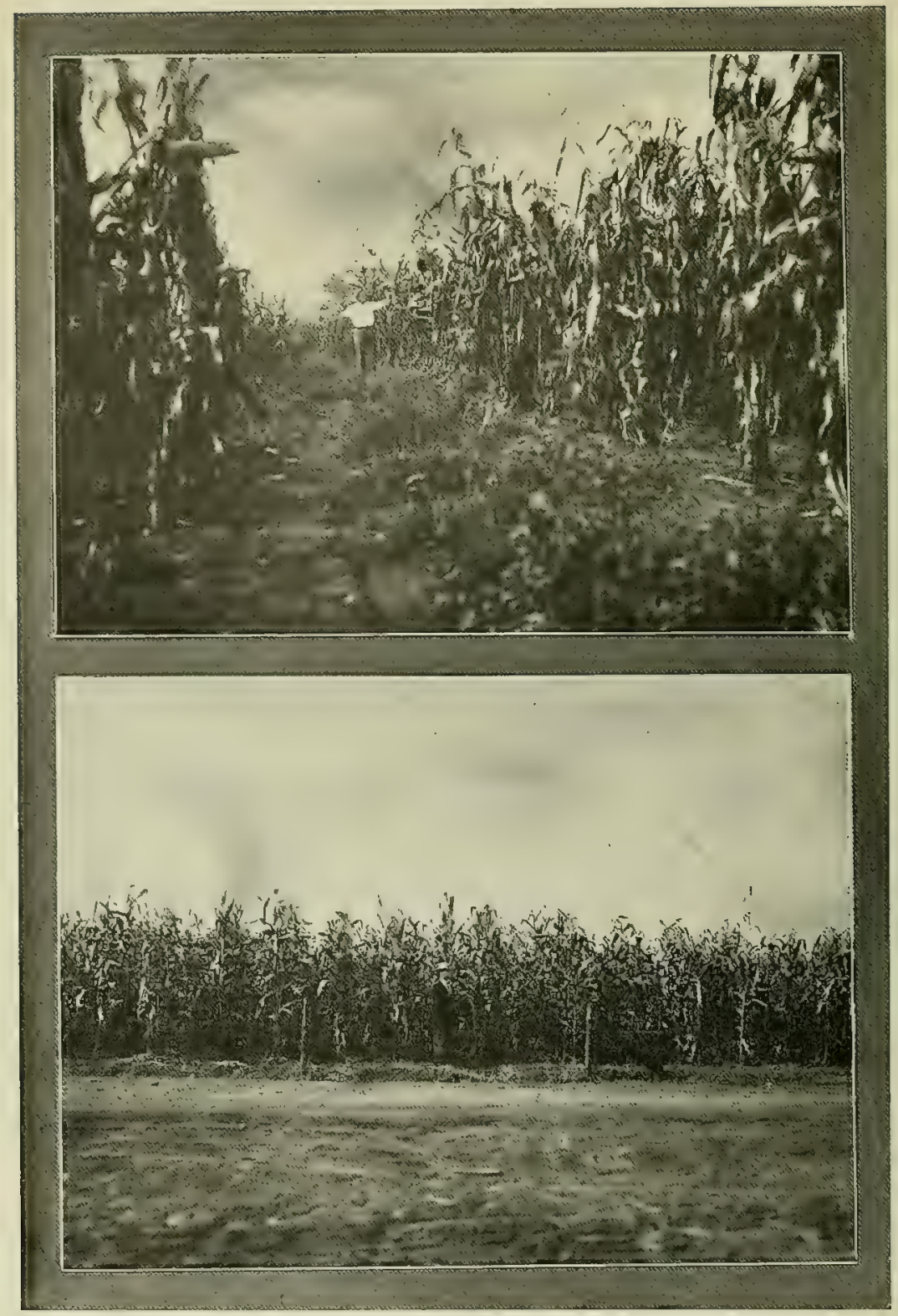

Corn

A barbed-wire fence roofed with the "canopy of heaven" makes an expensive tool shed. 


\section{IVE STOCK}

ture, and tends by chemical action to liberate the mineral plant foods.

It is very doubtful if advisable to break a heary clay soil early in the fall for corn, unless it is covered with a heavy growth of vegetation. When a heavy growth is turned under early, it has time to partially decay and the ground has time to settle. The freeze and thawing of a freshly turned sod lessens the liability of damage from cutworms in the spring. A heavy clay land deficient of hu-

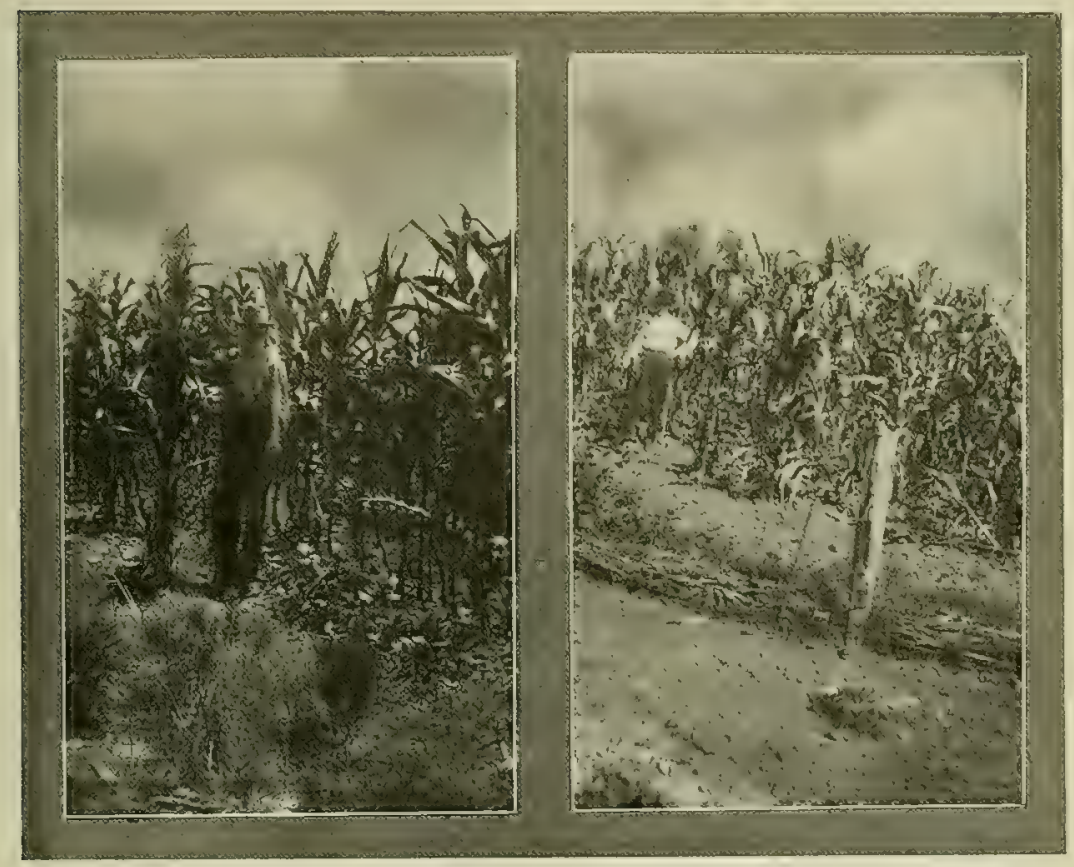

D. K. Wall's Corn With Peas in the Middle
J. B. Woodall's-Corn Field

mus, broken early in the fall, will be found to be so compact and run together by our heavy winter rains that the work necessary with disc harrows to get a proper seed bed will be found more expensive than the late winter or spring broken land.

Late fall and early winter are the proper times to break land deep. Often in the spring when the ground seems dry enough to plow, you will discover that only the top three inches are in con- 
dition; and if you set your plow to run five inches deep, you are plowing two inches of soil that is too wet. This is a very common mistake, and many have wondered why their corn "fired" or the yield was so low, when they had taken so great pains to break deep.

As the time for planting draws near, the ground should be thoroughly pulverized by roller or drag disc harrow. Time spent in thorough preparation before planting is time profitably spent. Use the best seed you can procure; seed that you have field selected. A little attention to the selection of seed will insure a perfect stand and an increased yield.

The thinner the land, the more space the corn should have. The most common practice in this section where corn is checked is to plant three and one-half feet by three feet ten inches, leaving two stalks to the hill on the rich lands and one stalk on the thin parts. Check corn is more economical of cultivation, as the hoe is never required.

On thin land, where corn must be helped out by commercial fertilizers, it is best to drill in wide rows; and at the second cultivation plant a row of peas in the middles, and the subsequent cultivation of corn will cultivate the peas.

If early in the corn-planting season, plant deep enough to insure moisture in case of a dry spell. Corn is more often planted too deep than too shallow. Just before the corn comes up, it is best to run over the field with a slant-tooth harrow; and when the corn comes up, start cultivation as soon as practical, giving it a thorough, deep cultivation. The cultivations should not be, over two and one-half inches in seasons of plenty of moisture. During seasons of dry weather the mulch should be established early and never be deepened in subsequent cultivations, for fear of destroying the feeding roots. In the cultivation of corn one must remember that the corn roots are matted across a four-foot row when the corn is only two feet high. To disturb these roots lessens the yield of corn. Cultivation of a light, shallow nature should continue until the corn is nearly made. Planting in water furrows has proven beneficial for late planting, and many claim that corn thus planted is not so apt to be blown down during storms.

Too often corn yields are diminished greatly after "laying by," a shower, followed by hot sun, forming a crust and permitting the 


\section{I VE STOCK}

moisture to escape just at a time when the corn needs the most moisture. Never permit a crust to form while the corn is filling. Work the ground from row to row with some light tool like the spring-tooth cultivator. Some seasons permit plowing to stop when the corn is beginning to tassel; then again the light cultivators have to continue until the corn is made.

The ideal cultivation of corn is often the shallow, but during adverse weather conditions shallow cultivation will be of little ben-

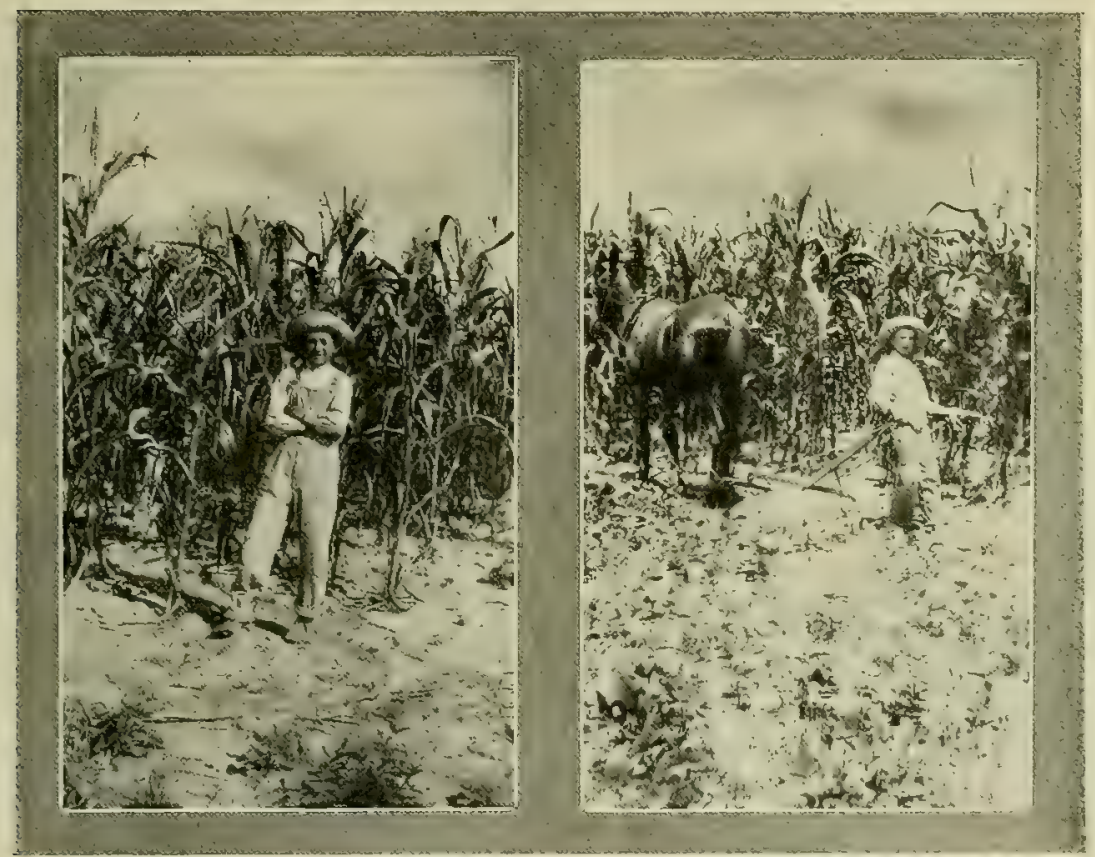

A Corn-Club Boy's Corn "Jungle"

A Corn Club Boy

efit when the soil has become compact and the weeds and grass have a good start due to excessive rains.

It is then that the ingenuity of the farmer is taxed. He must reestablish his depth of loose soil and destroy the weeds and grass with any tool best suited to the work, even though he has to do some root pruning. This root pruning is not as detrimental to the yield as that caused by a compact soil filled with weeds and grass. CLARENDON DAVIS. 


\section{BEEF CATTLE IN ALABAMA}

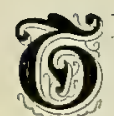

HE work of eradicating the "Texas-fever" tick is progressing satisfactorily in the Sonth. Every year new areas are freed from the tick, and with the progress of the work there comes an added interest in all kinds of cattle production. When the ticks in a county are exterminated, renewed interest begins to be immediately manifested in the beef-cattle business, as the South-

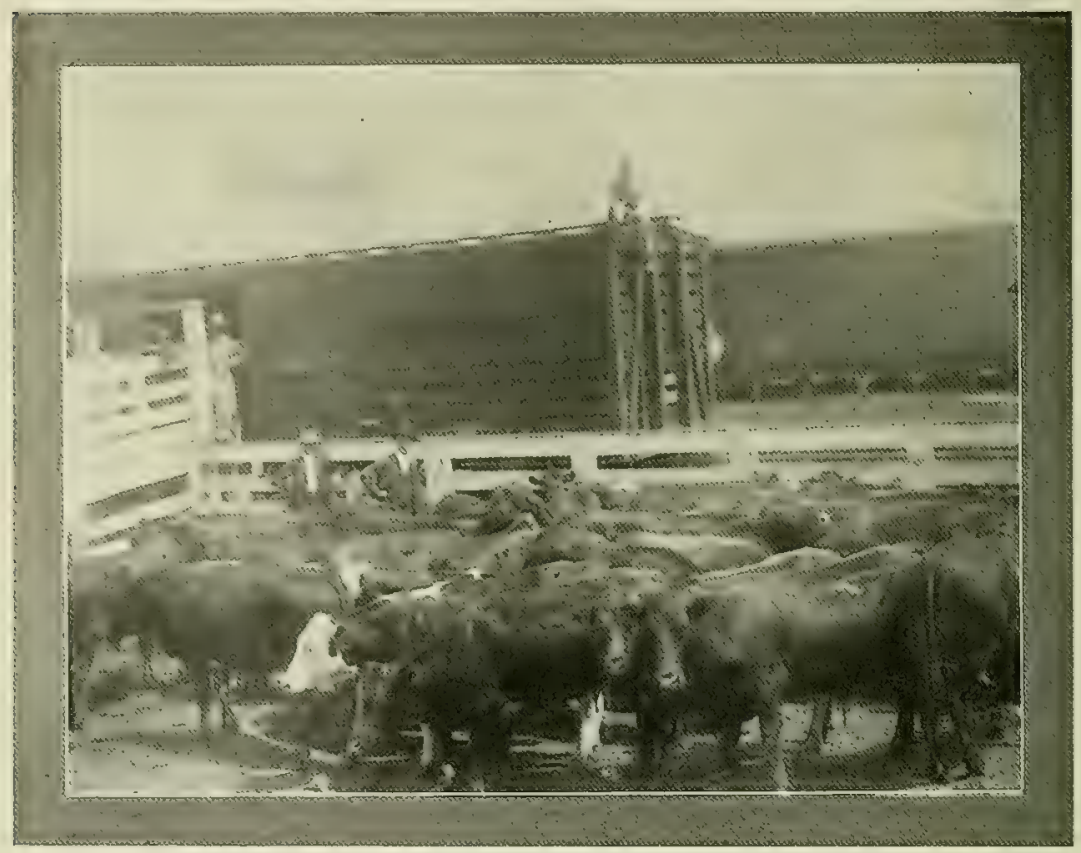

\section{J. H. Cummings' Cattle}

ern farmers now realize that the "Texas-fever" tick has been pracrically the only drawback to the cattle business in the past. When the tick is finally exterminated, no section of the United States will be as well suited to beef production as the South, because of its mild climate, long grazing season, and cheap lands.

There are many reasons why the Southern States should raise more beef cattle than are being raised at the present time. First, the South, under the present system of farming, has thousands of 
acres-and good ones, too-which are not being used at all. Statistics tell us that only about forty per cent of the tillable or arable land of the South is being used. Sixty per cent of the land is lying idle, and returns to the owner not a cent in wealth. All of the lands cannot be used as cotton lands, because, first, there are not enougl people to work the lands in any such way; and, second, many of these pauper acres are not suitable for cultivation. In fact, many acres that are now under cotton cultivation should be turned into permanent pastures and grazed with live stock. No State can become wealthy when only forty per cent of the land capital is being used. The grocer or the banker or the hardware merchant could not possibly make a profit on his business if he used only forty per cent of his capital; and the farmer cannot hope to be successful in his operations until he begins to make use of at least a reasonable proportion of his capital. No farming business can be made successful when only $\$ 4,000$ out of a possible $\$ 10,000$ is being used.

Then, again, beef cattle should be more generally introduced, because of the good they do in building up and maintaining soils. Under the present system of cotton farming, the soils are becoming poorer and poorer. With the introduction of cattle, the soil will begin to be buiit up. Director Thorne, of the Ohio Station, has been making tests with barnyard manure for several years, applying the manure upon a plat of ground upon which was running a three years' rotation of corn, wheat, and clover. Eight tons of manure an acre were applied. The average yearly increase an acre, following the one application, was as follows:

Corn, 14.7 bushels at 70 cents a bushel. . . . . .\$10 29

Corn stover, 744 pounds at $\$ 6$ a ton.......... 233

Wheat, 8.36 bushels at $\$ 1$ a bushel........ 836

Wheat straw, 897 pounds at $\$ 4$ a ton....... 179

Clover hay, 686 pounds at $\$ 12$ a ton....... 4. 12

Total value 8 tons of manure..........\$26 79

Total value 1 ton of manure.......... 335

The chauffeur of a one-mule-power bull tongue will never make a: record-breaking corn crop.

Page 31 


\section{LIVE STOCK}

He further states that the value of farm manure can be materially increased by balancing the manture with the addition of a carrier of phosphorus. The farm manures are too high in nitrogen as compared with the other elements. By balancing stable manure, the value of eight tons was increased $\$ 12.20$, after deducting the cost of the material used for the balancing of the manure. This is $\$ 1.53$ a ton, or, when added to the $\$ 3.35$ above, brings the total possible value of each ton of manure up to $\$ 4.88$. During a feeding period of one hundred days each steer will produce at least 1.5 tons of manure. This profit should be added to the feeding or direct profits. The Arkansas Station (Bulletin 68) made a test to determine the value, to each succeeding crop, of growing peas in the corn, gathering the corn, and then grazing both the peas and the stalks by the steers. The steers were being fed some cotton seed in addition to the grazing. As the result of this crop of peas and the grazing, the succeeding cotton crop was increased 626.5 pounds of seed cotton over the area where corn alone had been grown. A third lot was planted to corn, and the increase in corn, due to the pea crop and the grazing, was 14 bushels per acre.

A third reason why beef should be more generally produced in the South is that there is a demand for it, and the demand should be met in order that the money may be kept at home. During the year of 1907 there were about 15,151 home-raised animals slaughtered in the city of Birmingham (this includes cattle, veal, hogs, sheep, and kids), while there were 36,097 Western animals brought into the city and slaughtered. In addition to all this, thousands of pounds of cured meats were also retailed over the city.

This money should be kept at home and added to the Southern wealth. Packing houses are now being built throughout the South, and good markets are assured for the beef animals which the farmer produces.

The fourth reason offered in favor of beef production is that, as our farmers learn the value of diversification in farming operations, there will be an increased amount of roughage, as corn, fodder, cowpea, and clover hays, soy beans, etc., which many times can be marketed more profitably through the beef animals than in any other way. The beef cattle serve as important machines for converting the surplus fodders into valuable barnyard manure, which gives to 


\section{LIVE STOCK}

the growing crops not only the benefits of its fertilizing elements, but increases the mechanical condition of the soil by the addition of that important compound-humus. No animal can take the place of the beef steer in making use of the winter corn and cotton fields.

Beef cattle are peculiarly suited to fit the farming operations of the South. The farms are large, and many acres are not being used because of the lack of sufficient labor. At present there is no better way to put the whole farm to work than by introducing beef cattle into the system of farming. They require but a small amount of labor in addition to that used upon the average cotton farm. The hog, while he deserves a prominent place upon almost every farm, cannot be made to use all of the large uncultivated areas on the farms, for he is not strictly a grazing animal. Many farmers who have the large uncultivated areas are not now sufficiently skilled in the handling of live stock to introduce sheep or dairy cattle, as the sheep and dairy business require more skill than the beef business. Then, too, the dairy business requires an increase in the amount of labor used upon the farm, and the labor item is one that many farmers are trying to reduce.

\section{Pastures First, Then Live Stock}

The question of the introduction of more and better live stock of all kinds into the South is worthy of the careful and thoughtful attention of every one of our Southern farmers; but, unfortunately, many people do not understand that a man must be a good farmer, a good crop and pasture producer, before he can be a good and successful stock farmer-that is, many are prone to view the live-stock business from the wrong end. Many farmers labor under the impression that the proper way to start into live stock is to first procure the live stock.

The first thing to do is to establish pastures. This method of starting is all right if the farmer is so fortunate as to have fences to hold the animals when they arrive and good pastures within the fences for the animals to graze upon when released from the shipping crate. But the man who has never maintained stock upon the farm is usually not equipped with fences and pastures, and this kind of farmer cannot be impressed too strongly with the thought 
that pastures come before live stock and that pastures are essential to profitable live-stock production. The farmer who is not properly equipped with pastures should be made to know that the first step in the handling and feeding of live stock is the establishment and preparation of both permanent and temporary pasture crops, and that the animals themselves shotld be the last addition

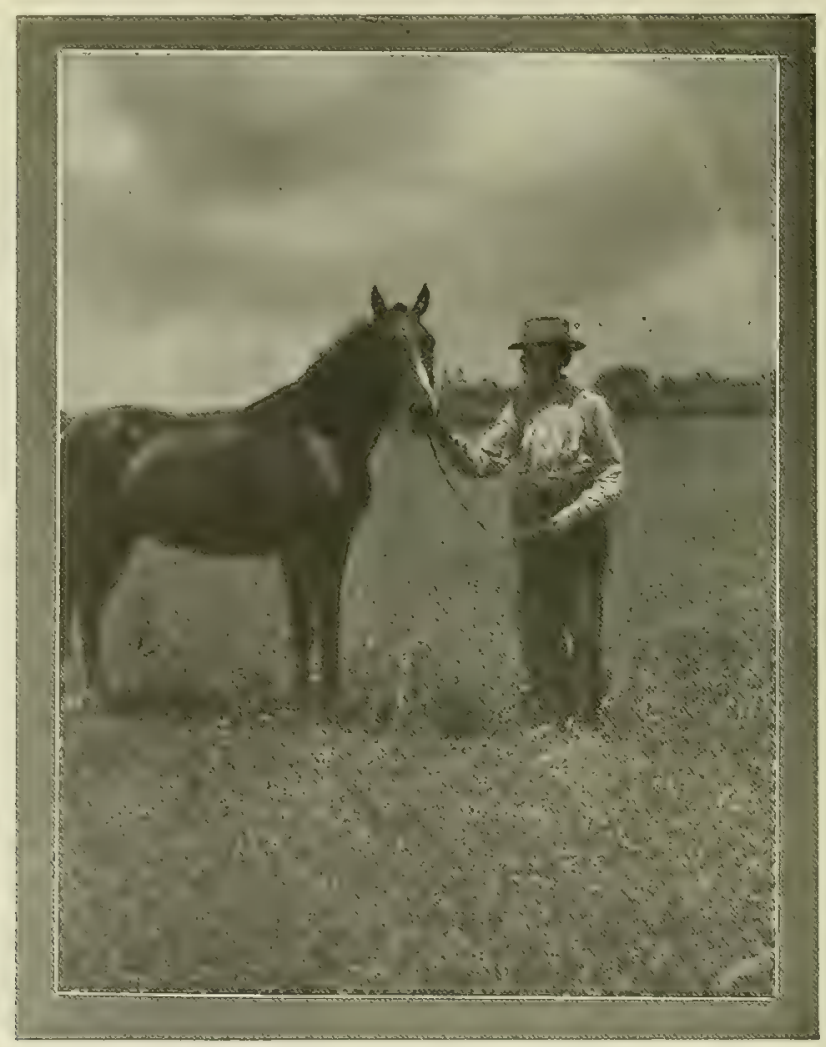

Red Clover and a Stock Raiser

to a well-equipped and properly appointed live-stock farm. Prospective live-stock men should understand that there is time enough to bring the stock to the farm after the feed and pastures are made and ready for consumption.

Thousands of farmers all through the South have gone into the stock business backwards, and a thousand other farmers are now thinking of traveling in the same way. The backward method of 
introducing oneself into the live-stock business is to bring the animals to the farm before the fences, fields, and pastures are ready to receive them. When the live-stock business is inaugurated improperly, the animals are necessarily put up in small pens or lots and fed solely on high-priced feeds or turned out into fields poorly fenced and poorly sodded with grass. Such unfavorable conditions soon discourage the owner. He soon realizes that a mistake was made in getting the stock before the pastures. In short, the unfortunate owner soon realizes that he went into the business backwards, and he usually continues to back until he has completely. backed out of the live-stock business.

Don't go into the business backwards.

The farmer who has had such an experience knows why he failed. He also knows that if he had started right there would have been no failure; but the unfortunate thing about it is that the neighbors oftentimes do not know, and they naturally conclude that live stock cannot profitably be made a part of the Southern system of farming. It is far better for both the individual owner and the country that no start at all be made in live stock than for a start to be made in such a way as to insure failure.

We do not need to give special illustrations to prove that farmers who have tried to grow and produce animals without pastures as a basis almost always fail. Neither do we need to give special illustrations to prove that in almost every case where stock have been kept at a profit, pastures were responsible for the success.

The man who realizes that the pastures afford the cheap feeds for all kinds of live stock, that the establishment of pastures is the very basis of successful live-stock production, that a man must be a good farmer before he can be a good and successful live-stock owner, never, or seldom, sees the time when his animals fail to render an exceedingly satisfactory profit. The farmer who has good pastures soon learns that they save from fifty to seventy-five per cent of the high-priced grains.

In short, the chief business of the live-stock farmer is to have good pastures as many months of the year as possible. To produce live stock at the highest profit, the animal should be made to think it is summer all the time.

Pay with a check; for when cashed, it is the best form of receipt. 


\section{LIVE STOCK}

\section{The Kind of Cattle}

No one should be made to think that money can be made on beef cattle, even with the very best system of pastures, unless gocd cattle are raised. By "good cattle" it is not necessarily meant that they must all be pure-bred animals, but it is meant that the male must be a pure-bred animal of some one of the recognized beef breeds. To begin with, the corvs may be, and necessarily must be, the common cows of the county. But it should be understood that no progress can possibly be made towards better cattle and more money when the common bulls of the county are also employed. This has been done already year after year, and nothing but disappointment has resulted. Pure-bred bulls should always be used; and each farmer, before beginning the beef-cattle business, should decide upon the breed best suited to his particular farm and locality, and then everlastingly stick to that breed. When it becomes necessary to change bulls to avoid inbreeding, never change the breed; always stick to the breed you started with. When this is done, it will be only a few years until a good herd is built up which any man may be proud of.

\section{The Breeding Herd}

While farmers differ in their opinion as to whether bulls should be allowed to run with the cows, the writer believes that the best plan, when everything is considered, is to have the bulls be with the cows during the breeding season, but temove them just as soon as the season is past. Of course, breeders of pure-bred animals could not follow this plan. In Alabama the calves should come during the early spring months. Under average Alabama farm conditions it is better to have no calf at all than a late one, so the bull should be taken away from the cows early enough to avoid the raising of late calves.

If the pasture is of good quality and abundant, the cows and calves will require but very little attention during the summer months. Ordinarily no supplementary feeds, except salt, will be 1tsed during the pasture season.

But when fall arrives, both the mothers and the calves must have extra feed and care. The calves must now be taken away from their mothers and fed alone. The mothers themselves must be 


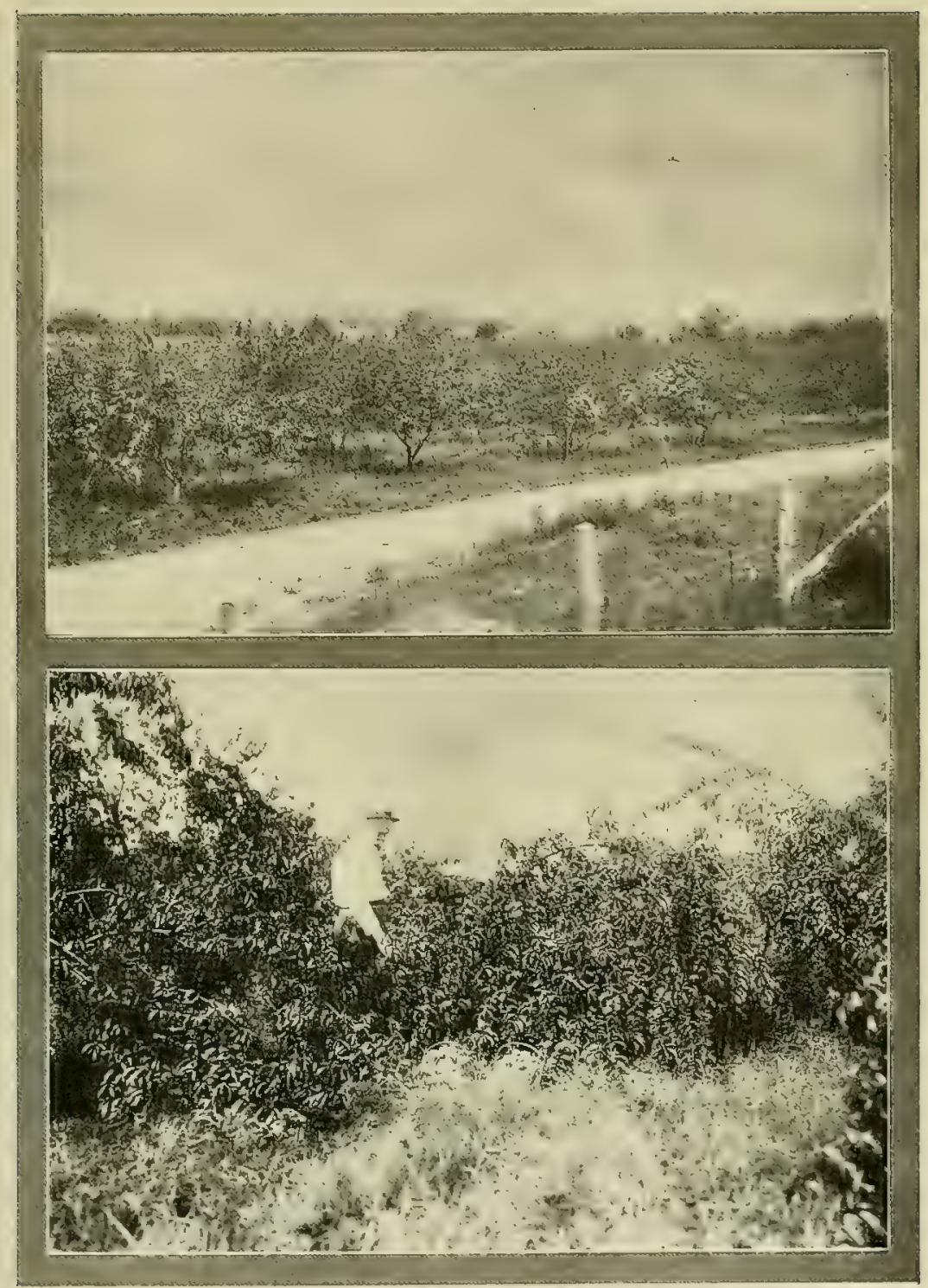

1. Orchard. 2. Peach Orchard

kept in condition for producing the next crop of spring calves. If the mothers be expected to produce large and strong calves and nourish them well after they are born, they must receive both good care and attention throughout the cold months. By this it is not 


\section{I V E S TOCK}

meant that these cows must be fed all winter on high-priced feeds altogether. They should not, however, be permitted to run down noticeably in flesh, but it is not necessary to make use of large amounts of high-priced feeds in order that the weights of the cows be maintained. The breeding herd should be largely maintained upon cheap roughage, some of which may be entirely unsalable. The kind of roughage used will vary. Some farmers make large use of oat straw and corn stover. A cow may be wintered in good shape on oat straw and corn stover when they are supplemented with two pounds of clover hay a day. This is cheap ration, and one which, under ordinary farm conditions, will prove to be satisfactory. Corn silage, when available, is undoubtedly one of the cheapest and best feeds to be used as the principal part of the winter ration of breeding cows. A daily ration of about eighteen pounds of corn silage, plus two pounds of clover or cowpea hay, together with all the oat straw the cow will eat, will be sufficient feed to cause a small increase in weight during the cold months. This ration, as the farmer knows, is an exceedingly cheap one. The breeding cows should be made to use the cheap roughage of the farm. This is one of the main uses of the beef animal on the farm. The business of producing beef cattle cannot be made a profitable one when only high-priced feeds are fed.

\section{Fattening the Calves and Steers}

The beef-cattle business can be, and usually is, divided into two parts-breeding and fattening. As a rule, the man who raises the calf does not finish it on his own farm for the market. He usually sells it to a neighboring farmer who makes a business of fattening and preparing the calf or steer for the market. Thus the feeder oftentimes has no interest at all in raising the calves. Probably the ideal condition, at least for Alabama and adjacent States, is for the calf to be raised and finished on the same farm. But this ideal condition can seldom be realized, because the man who raises the calf has, as a rule, only a few cows, and can seldom afford to take the time and trouble to fatten the few calves which these cows bring each year. Even if the small farmer were to fatten these few calves each year, he could seldom afford to ship them to the large markets, so he is at the mercy of the local buyers. As a result of 


\section{I VE STOCK}

this condition of affairs, the professional feeder has developed. His business is to collect calves and steers into car-load lots and prepare them for the open market.

The farmer who has as many as thirty breeding cows on his farm should make it a rule to fatten their offspring himself. He can seldom afford to sell the calves to the professional feeder. The feeder usually makes money on the process of fattening, and the man who raises calves in sufficient numbers should keep this extra profit at home. Furthermore, the farmer who has from eight to twelve calves or steers ready for the feed lot will usually find it profitable to buy a sufficient number of feeders to complete the load, and he can then finish all of them on his own farm.

There are many ways of disposing of beef calves or cattle, and the farmer should be watchful to avoid methods by which money might be lost. It is possible to raise beef cattle properly and by selling them improperly to lose money on the business in just the same way that it is possible to raise good apples, potatoes, and peaches and lose money on them when the marketing part of the business is not studied and given proper attention. When beef cattle are bred, fed, and marketed in a scientific and businesslike manner, satisfactory profits should be realized.

The farmer who raises calves is often at a loss to know at what age they should be disposed of. The spring calf may be sold the subsequent fall. It may be fattened during the winter months and sold as a fat yearling calf; it may be kept on the farm until it is from two to four years of age and then sold to a professional feeder; or the mature steer may be fattened on the farm where it was raised instead of being sold to a feeder. On account of the various methods which it is possible to adopt for disposing of beef animals, the owner is often in doubt as to the most profitable manner of handling and disposing of his crop of calves. In the past our farmers and planters insisted on keeping the offspring of their beef cows until they were from three to four years old, but many inquiries are now made as to the advisability of fattening the calves so as to dispose of them by the time they are a year old.

There may be " no plows in the pawn shop," but plenty of them are covered with rust and chattel mortgages. 
Two or three points can be urged in favor of this system. First, more breeding animals can be kept upon a farm when the offspring are disposed of at an early age than when they are held and sold as steers. Second, the younger the animal, the cheaper each pound of beef is made. Third, the money invested is turned more rapidly when the calves are sold at a young age.

\section{Fattening Yearling Calves}

During the winters of $1910-1911,1911-1912$, and 1912-1913, the writer, working in coöperation with the Bureau of Animal Industry at Washington, studied the question of fattening beef calves during their first winter and selling them the following spring when they were about one year old. In the first test the calves, which averaged 338 pounds in weight at the beginning of the fattening period (November 17), were divided into three lots and fed upon different feeds. The first lot was fattened on a ration made up of cotton-seed meal, cotton-seed hulls, and alfalfa hay. The second lot of calves was fed a grain ration of cotton-seed meal and cornand-cob meal in the proportion of two to one, cotton-seed hulls, and alfalfa hay. The third lot was fed the same feeds exactly as those given to the second lot, except that the relationship between the cotton-seed meal and hulls was reversed. They were all fed under a good shelter. Calves will not do well unless they are protected from the cold winds and rain. They all made good gains, making $1.71,1.76$, and 1.83 pounds per calf per day in the respective lots. When they were sold, March 17 , their average weights were 541, 543, and 546 pounds in the various lots. When these calves were taken from their mothers, they had cost $31 / 2$ cents a pound. When they were sold, March 17, at Cincinnati, each one hundred pounds brought $\$ 5.01, \$ 5.11$, and $\$ 5.26$ in Lots 1,2 , and 3 , respectively; so they netted a satisfactory profit above all expenses of raising and fattening. This proved to be a good way to dispose of the corn and alfalfa hay, as the corn was sold, by means of the calves, for 95 cents to $\$ 1.90$ a bushel, while the hay was marketed through them for $\$ 20.72$ to $\$ 21.25$ a ton.

In the second test, fifty-two calves, which averaged 313 pounds in weight when the fattening period began on December 10 , were fattened on a ration made up of cotton-seed meal, cotton-seed hulls, 


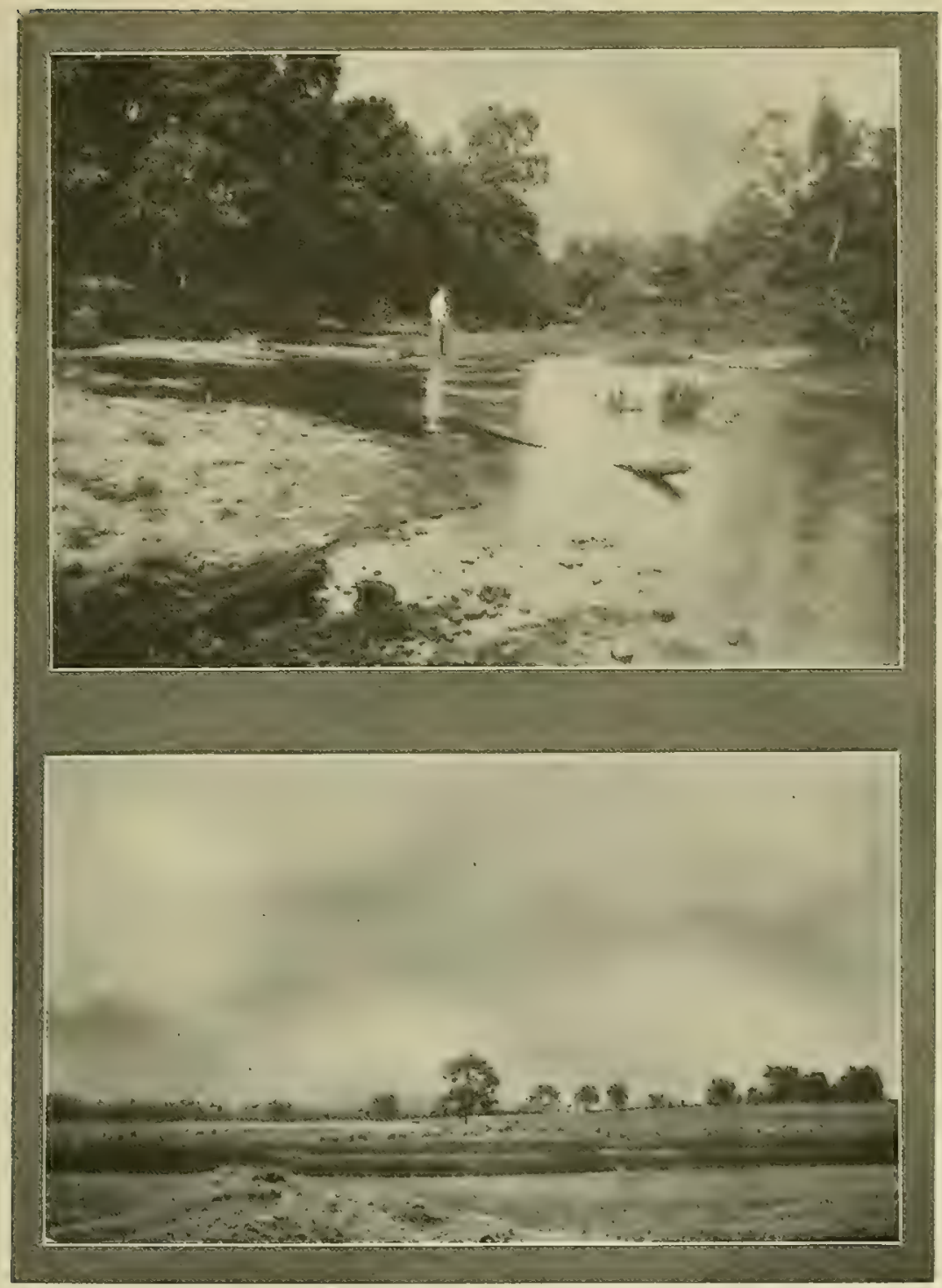

\section{One of Many Clear Streams. 2. A Farm in Madison County}

and cowpea hay. The calves were fed from December 7 to March 29 , when they were sold at New Orleans at $\$ 5.55$ per hundred weight. These calves also did well, as they gained at an average daily rate of 1.24 pounds. At the end of the test they had attained Page 41 
an average weight of 452 pounds, and were probably ten to eleven months old on the average. It cost 3 cents a pound to raise these calves up to weaning time; they sold, as stated above, for $\$ 5.55$ per hundred weight. They also realized an exceedingly satisfactory profit, as each calf netted a clear profit of $\$ 3.50$ above all expenses of raising and fattening. It is true that not much hay was fed (more could have been fed at a profit), but what was fed was sold from the farm by means of the:calves for $\$ 56.61$ a ton. Hay and rough feeds can almost always be sold by means of calves for more money than can be secured for these roughage when sold in the raw state.

It should be added that all of the above calves were good ones; they were not scrubs. It would have been impossible to have made profits if scrubs had been used. These calves, however, were not pure-bred animals; they, were only grades which had been secured by the use of pure-bred bulls on the native cows.

\section{Fattening Steers}

In both the West and the South there are some farmers who prefer to keep the offspring until they reach an age of from two to three years. When this is the case, there are two general ways of preparing them for the market. They may be fattened during the winter months on cotton-seed meal and hulls or other combinations of feeds, or they may be fattened during the summer months on pasture and sold some time at the end of the pasture season. Each system has its peculiar advantages. The main advantage in feeding during the winter months are: (1) The feeder has better control of the manure; (2) the farm work is not so urgent during the winter months; and (3) many farmers can feed cattle during the cold months who have no pastures for summer feeding. The chief advantages in fattening steers during the pasture season are: (1) As a rule, one can make more clear money on steers which are fed on pasture than when fed in dry lots; (2) the labor of feeding in the summer time is a very small item, as the cattle are fed only

The head of the family should not be the only one having a bank account. The wife, daughter, and son should start a savings account, drawing four per cent interest. 
once a day: and (3) the pastures are rapidly built up from year to year, and without the expense of hauling manure.

In winter fattening one has the choice of many feeds, but there are three or four feeds which can be used to the greatest advantage. As the cheap and damaged roughage of the farm should be fed to the breeding rather than to the fattening animals, we will assume that the cheap straws, the stover, and the damaged hays are all used in another direction. However, if there are no breeding animals or stock cattle on the farm, these cheap feeds should constitute a part of the ration for the fattening steers. These cheap feeds must be saved; they must not be allowed to rot on the farm; they are valuable. The writer has tried many feeds and combinations of feeds for fattening steers during the winter months, and he has found only one that is better tinan cotton-seed meal and hulls. The ration that is superior to cotton-seed meal and hulls is cottonseed meal, hulls, and corn silage. Of course, the majority of our farmers do not now have silos, and for those who do not have them at the present time it will be a difficult thing to find a ration better and more economical than cotton-seed meal and hills, especially when they are supplemented with one of the cheap roughage feeds of the farm. The writer fed one buncl of cattle on cotton-seed meal and hulls; another binch on cotton-seed meal, hulls, and Johnson-grass hay; and a third bunch on cotton-seed meal, hulls, and corn silage. On the first bunch a clear profit of $\$ 6.97$ was made on each steer; on the second bunch $\$ 5.50$ was made on each steer; and on the third bunch, the silage-fed cattle, a clear profit of $\$ 7.68$ was realized on each animal.

When steers are fed during the summer season on pasture, they, as a rule, must be purchased, if the owner does not raise them himself, the previous fall. It is practically impossible to buy steers to advantage after the arrival of spring. Now, how shall these steers be cared for and fed during the winter months? If they are to be fattened during the subsequent summer, it is unwise to try to make them gain during the winter months. It is a fundamental principle in feeding steers that the more they gain during the winter months, the less they will-gain the subsequent summer. So these steers should be fed on the cheapest feeds the farm affords. They should not, of course, be permitted to become weakened dur-

Page 43 
ing the cold months. These are the very animals, however, that should be made to make use of the stock fields; of the straw stacks, and of the cheap stover and damaged hays. The farmer who has silage may use a small amount of this succulent feed to advantage. Grains and high-priced feeds should be used sparingly. with these steers. The owner should look forward to making the gains the following summer; then they can be made cheaply.

As soon as grass comes, the steers should be turned upon it and fed a small amount of cotton-seed cake each day about sundown, if they are to be sold as fat cattle at the end of the season. It will pay to feed the small amount of cotton-seed cake along with the pasture. There is no doubt about this. The writer has tested this out thoroughly. For five years we fattened one bunch of cattle on pasture-nothing but pasture. Right by their sides were other cattle which were fattened on the same kind of pasture, with three and one-half pounds of cotton-seed cake per steer per day as a supplement. The steers which were fattened on pasture alone returned a clear profit of $\$ 5.69$ each, while those which received the cotton-seed cake as a supplement returned an average profit of $\$ 7.08$ each. It paid to feed the cake. DAN T. GRAY, Professor of Animal Industry, State of North Carolina.

\section{MONEY IN FEEDING BEEF CATTLE}

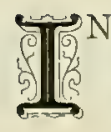

the fall of 1912, Mr. J. H. Cummings, of Chase, Ala., purchased thirty-six head of cattle and fed them on his farm, selling them in the spring at a handsome profit. His success, which he has given us in figures, should convince the most skeptical of the profits to be made with beef cattle fed silage.

Mr. Cummings paid for his silo and all his work and had left a wide margin of profit and eighty per cent of the fertility contained in the feed left on the farm. Had there been more silage, he could have eliminated the cost of the cotton-seed hulls. These cattle had only eight acres of silage, which was not quite enough, and this had to be supplemented with the cotton-seed hulls.

Mr. Cummings has pointed out the way to a money-making prop- 


\section{I VE STOCK}

osition to the farmers of the Tennessee Valley that will add fertility to the soil and eliminate the cost and worry of the present tenant system, besides the money return that insures a cash balance for the year's work, as the following figures will show:

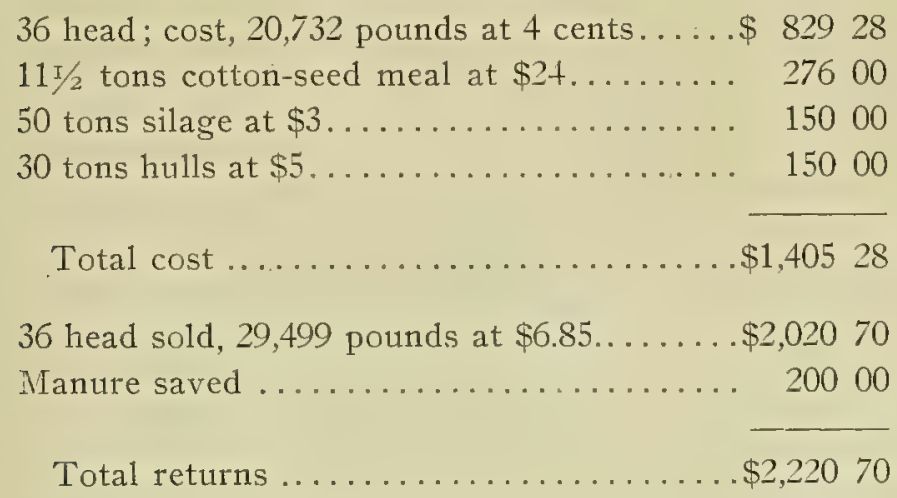

Leaving a profit of $\$ 815.42$ on an investment of $\$ 1,405.28$ for the short feeding period of a little over four months.

Mr. Cummings paid $\$ 200$ for his silo, and from his last year's experience he could well afford to buy a silo every year.

\section{ADVANTAGES OF LIVE STOCK AND SILOS}

(D)

UCH thought has been given to dairying and live-stock interests in the Southern States in the last few years. This has been caused partly by the advent of the cotton boll weevil.

Alabama holds exceptional advantages, especially along the Tennessee Valley. We need to change our system of farming by diversification; and to do this, live-stock interests are sadly needed.

With our mild climate and long growing seasons, we have overlooked the advantages which stand out so prominently before us.

The high prices of meats to-day and the millions of dollars that go annually out of the South for dairy products should make us give these industries serious thought. With dairying and live stock we are continually turning over our money, and at the same

Page 45 


\section{I V l: STOCK}

time building up our farms from the valuable manure from our herds. With the dairy cow, we have a monthly cash business. Besides this, a cow is good for ten years and gives us a calf each year, from which we can soon build up a good herd. Start with a few

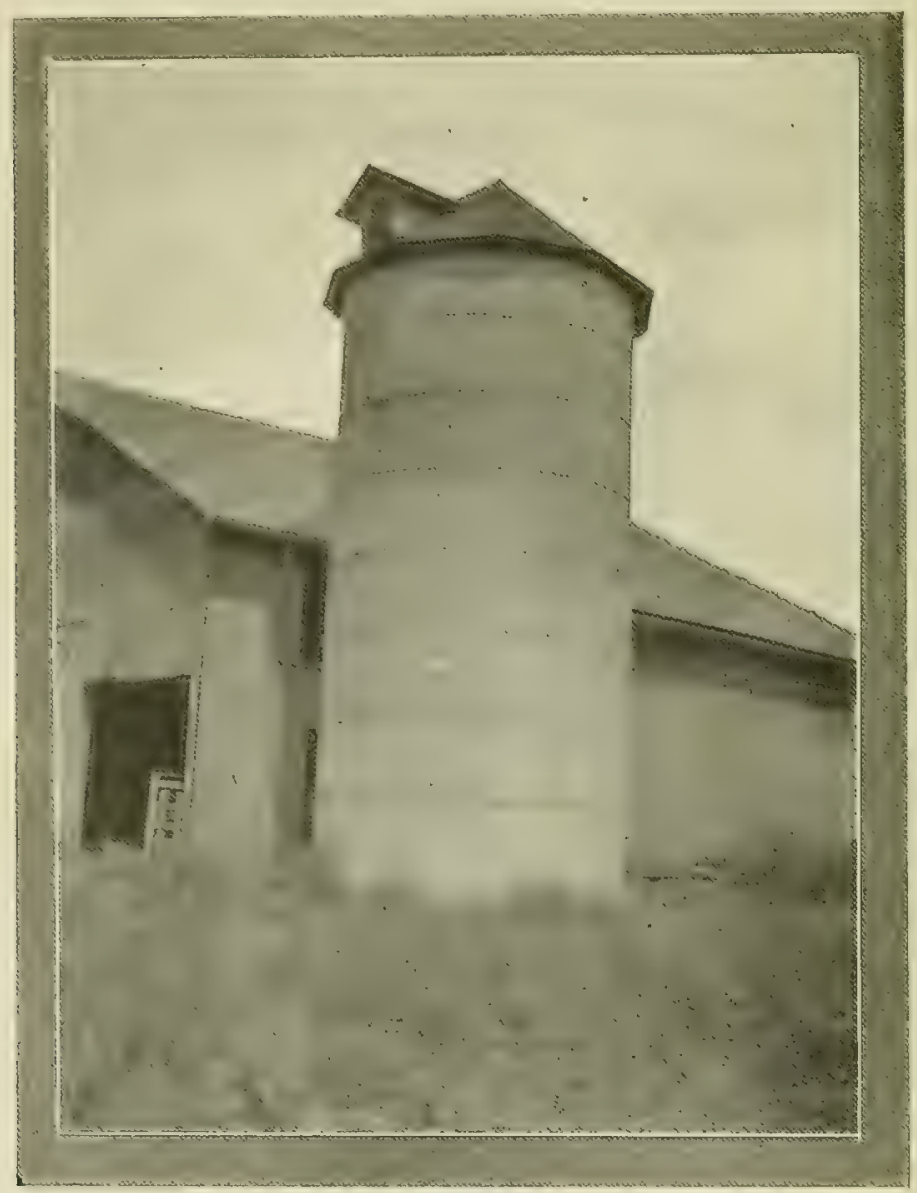

J. H. Cummings' Silo

good cows and breed them to a thoroughbred bull, take care of the heifer calves, and before you realize it you will have a dairy herd which is a constant source of income.

Using a check book denotes businesslike methods and lends dignity to the user. 
Live stock is a factory to the farm in which the crops grown are consumed; and where the manure is properly cared for, two-thirds of these crops are returned to the soil. Too much of our soil is lacking in humus, caused by the lack of diversification and live stock. With proper cultivation, our soil should improve and become more productive; and these soils can be vastly improved with live stock on the farms and the leguminous crops which form a great part of their feeding rations.

Where cotton is the principal crop, the farmer is generally short of cash through the growing season; but with a small dairy, for instance, he always has a cash income, which makes him more independent and gives him a better standing in his respective community.

Good cattle, with proper care and feeding, is the secret of success; and the proper feeds can be grown on the farm, and should not be bought from the mills. Both beef and dairy cattle need an abundance of rough feeds and forage, such as hay and silage. We have an abundance of forage crops to choose from, such as cowpeas, soy beans, velvet beans, vetch, and the different varieties of clovers, practically all of which can be grown in this Tennessee Talley.

With reference to silage, this is one of the cheapest and most economical feeds produced, and no farm with ten or fifteen head of stock can afford to be without a silo. Silage makes a bulky succulent feed, of which all cattle are very fond at any time of the year. They thrive on this feed, and it keeps them in a healthy condition. It puts meat on the backs of beef cattle and increases the milk flow from a dairy cow. Practically any crop can be cut up and put in the silo, though corn seems to be the ideal crop. Corn needs to be put in the silo at what is known as "fodder-pulling time," or in the advance roasting-ear stage. With the silo, we save our entire crop of corn ; but where the stalks are left in the field, we lose about forty per cent of its value. The cost of a silo is small compared to its value, and it will pay any farmer to investigate this money-making: crop-saving device. Silage to cattle is what canned vegetables are to our tables out of the growing season. In building silos, we need community spirit, which will reduce the cost of filling our silos. It takes an engine and a cutter to put this feed in the silo, but one 


\section{LIVE STOCK}

cutter and engine will easily fill the silos at half a dozen or more farms. Silage is worth at least five dollars per ton, and it should

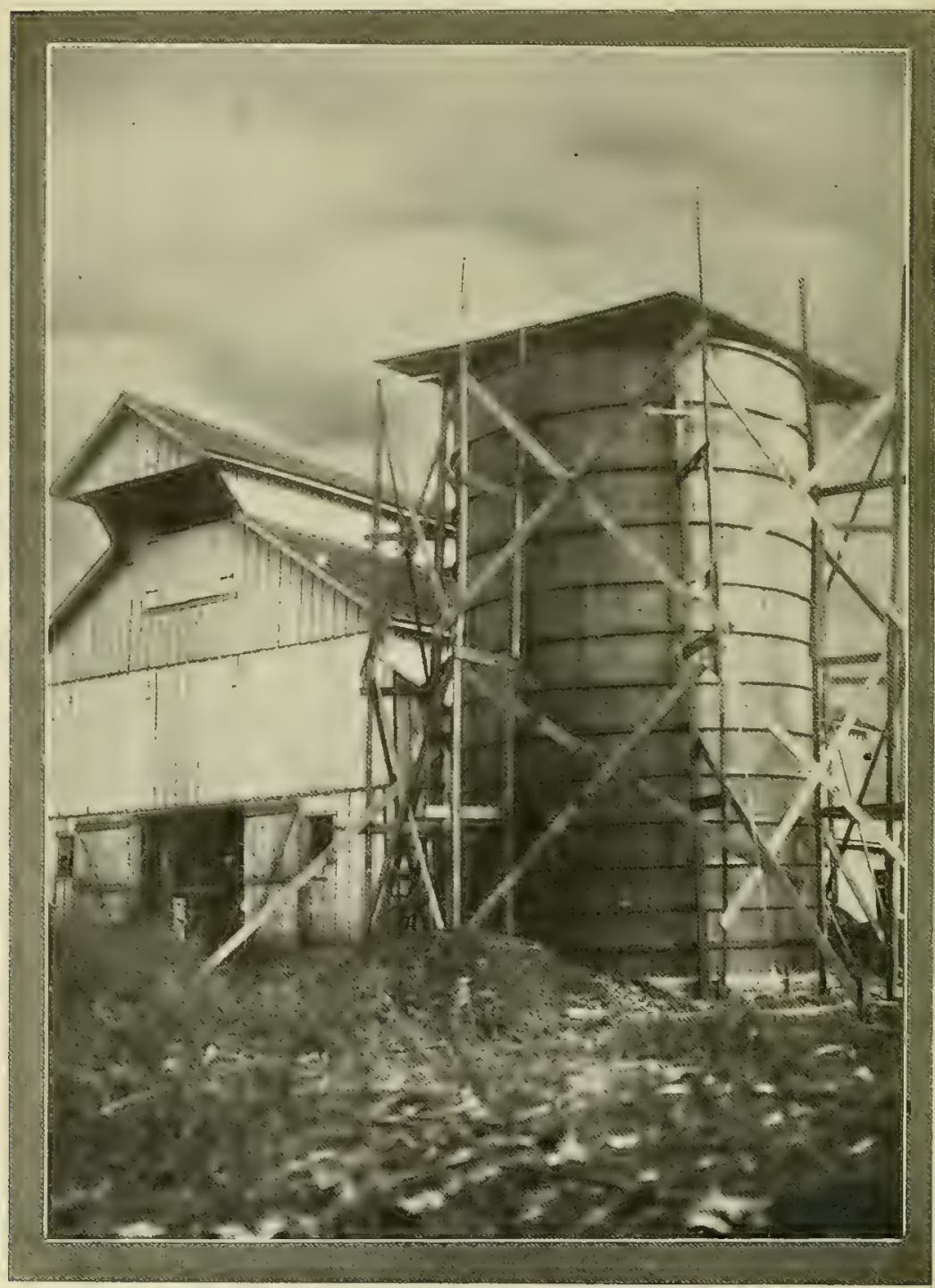

Silo Built and Filled Within Ten Days; Capacity, 120 Tons; Cost, $\$ 120$

be grown and put in the silo for two dollars a ton. An acre of good corn will make ten tons of silage. 


\section{LIVE STOCK}

Many Southern farmers have a few cows and heifers on their farms, and they are selling these to men who offer them what seems to the farmer like fancy prices. Keep these cattle on your farms and breed them up, as other people realize the scarcity of breeding cattle. When you sell these cattle, you are selling the foundation of the cattle industry on your farms. The high prices of meats in the last few years have caused cattle buyers to scour the country, and thousands of our Southern cattle are being shipped into the Northwest. Dairy and beef cattle, poultry, and hogs mean more money and better farms, and we have the market if we will only produce the goods.

G. W. HUXPHREY,

Dairy Expert, Sonthern Railroad.

\section{HOG RAISING IN ALABAMA}

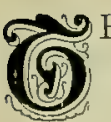

HE production of swine for market is not a specialized industry in Alabanna, but should be, and would be profitable, especially when associated with other lines of farming. Numerous beginners are seeking information on the care and management of hogs, and even experienced swine breeders are asking for advice.

It is my purpose to advise the beginner and answer a number of questions which frequently confront the everyday hog raiser.

\section{Importance of Type}

The farmer who would succeed in hog breeding must have a well-founded knowledge of the two types of swine. By "type" is meant the general conformation of the animal. All breeds are included in the two types-that is, the lard type and the bacon type. The breeds may differ in color, shape of head, or hang of ear: but the general conformation is practically the same. The PolandChina, Duroc-Jersey, Berkshire, and Chester-White are known as the lard hogs. They are broad, deep, heavy-fleshed hogs, and are of American origin. They have been developed by selection and continued feeding on a fat-producing ration. The bacon type, on the contrary, is a long, narrow, deep, thin-fleshed conformation. 


\section{I VE STOCK}

The large Yorkshire and Tamworth are the principal breeds of the bacon type. They are of foreign origin, and have been developed on nitrogenous rations. As the result of careful breeding and feeding, the bacon breeds have been developed to a high state of perfection, and make the best quality of pork.

As conditions in Alabama are unlike those in the corn-belt States. where the great majority of hogs are produced, the question often is asked: "Why not produce the bacon hog in Alabama?" A majority of experiments show that all breeds of the same type do

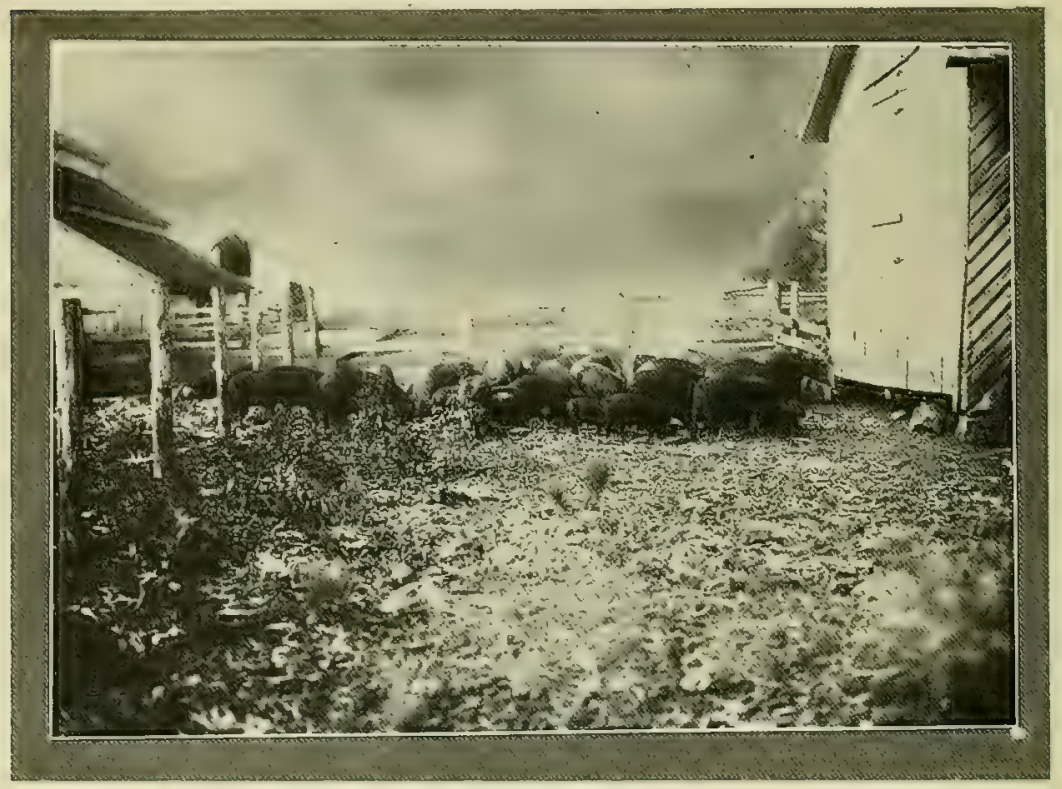

Duroc Hogs

equally as well under similar conditions. The bacon hog, compared with the lard hog, with which he comes in competition, dresses but seventy to seventy-five per cent. 'The dressed weight, compared to the live weight, practically decides the value of all hogs in the great market of the Central West. On this account, and the fact that packers can secure and utilize a sufficient supply of immature and unfinished lard hogs in place of true bacon hogs, there is as yet no well-established market or demand for the latter class of animals. Although conditions in certain localities of this 
State are suitable for the production of bacon hogs of high quality, their breeding and feeding should not be undertaken in competition with the lard hog, unless in particular centers the demand is sufficient to insure prices leaving a profit over the cost of production.

\section{The Selection of a Breed}

Having studied the two types of swine and decider that, at present, the lard type of $\log$ is, in most cases, preferable for market production by Alabama farmers, the question next arises as to which breed of lard hogs should be selected. The four leading breeds of lard hogs may be classed according to numbers, as follows: Poland-China, Duroc-Jersey, Berkshire, and Chester-White. Each of these breeds is well established, and possesses and transmits the characteristics-low-down, symmetrical conformation-of the lard type of market hog. Each farmer should select from these breeds the one that, on the whole, best suits his particular conditions, judging from his personal preference, his method of production, the local popularity of the breed, and the market demands. The most desirable market hogs are those of uniformity in breed and type, combined with finish and quality. There is so little difference between the breeds, when properly handled, that the results obtained will be due to the intelligence of the breeder rather than to the merits of the breed itself.

\section{Selection of Breeding Stock}

Swine offer a greater opportunity for improvement and upgrading than any other class of live stock. There is no reason why any farmer raising hogs should have a herd of scrubs and inferior individuals. Starting with a pure-bred sire and continuing to use a sire of the same breed, but a few years are required to establish, at little expense, a grade herd equal to pure breeds in every way for pork production. No class of animals increases so rapidly and none so readily retains the acquired characteristics. Even when start-

Deposit the sale of your cotton and other farm products with us, and let us enter them on your passbook. Check it out as needed. At the end of the year your passbook will show what every crop made, and your checks will be a receipt for every dollar spent. 
ing with an inferior lot of sows, a uniform herd can be developed by using a good boar and each succeeding year rejecting all inferior animals from the breeding herd.

\section{A Good Boar is Essential}

The most detrimental factor to swine breeding is the "scrub". boar, for he has neither individuality, good breeding, nor any quality worth transmitting. The herd boar should be pure bred and have individual merit and character. Pure breeding should insure prepotency in the sire and give uniformity and character to his offspring. The breeder should become a competent judge and study the type, shape, and conformation of his animals under different ages and conditions.

\section{Practical Swine Management}

The sire should be strong in the characteristics of the breed and possess the type of market class to which he belongs. While the boar may well have the proper color markings and points of the breed, it is all important that he should possess a combination of size and quality. A sire of the lard type should be short and broad in the face, broad between the eyes, and have short, broad ears. His neck should rise rapidly behind the ears and widen into a body which is long, uniformly. wide and deep. Boars often become too wide and rongh in the shoulders, with deep wrinkles in the skin. The thick plates of hard skin on the sides of the shoulders are sometimes called "shields." Mature boars are liable to develop massive forequarters and be narrow behind, with insufficient depth in the llams and twist. Sires of this sort should be avoided. Seek refinement in the head and forequarters, with a broad, strong, slightly arched back, a wide loin, and wide, deep hams. It is imperative that the legs and feet of a boar be short, strong, and sound. The tendency has been to pay particular attention to the hog's conformation of body and too-little to his legs and feet. The legs below the knees and hocks should be of medium size and free from fleshiness or wrinkles in the skin.

Good bones have quality and proper shape. Size and coarseness do not always indicate strength. The pastern of the hog should be short and upright, giving strength and support to the limb above 


\section{LIVE STOCK}

and the foot below. After having selected the boar, with reference to his individuality and family characteristics, quarantine him for at least three weeks before 11 sing for service. Parasites and disease are often introduced by newly purchased animals. During the period of quarantine handle the boar and get him into proper shape for service by proper feed and exercise. He may have the run of a small grass paddock, and, if young, may be fed three times a day; if mature, twice a day will suffice. When the boar is five or six months old, he will do best if kept by himself, and should not be used for service until seven and a half or eight months old. As a general rule, it is inadvisable to allow a boar to serve more than once a day, and he should not be used immediately after feeding. Early in the morning is the best time to use him. The boar should be treated two or three times a year with crude oil, as prescribed in the treatment for lice, to keep his hair and skin in proper condition. When over a year old, the feet often need trimming. The tusks should be cut with a large nipper or pinchers twice a year, and not knocked out with a cold chisel. The latter cruel practice often results in fracturing the jawbone and causes serious trouble.

A tried sire should be used as long as possible, for such an animal is the surest proposition and should not be disposed of before a successor has been sufficiently tested.

\section{Selection of the Brood Sow}

The sire is often considered half the herd, but in reality the females are equally important. The typical sire will transmit his qualities of excellence to his get, but the best results will only be had when he is mated with proper.clams. The dams should have the same combination of size and quality requisite in the sire. In conformation she need not be so compactly built, and may be somewhat finer in features and bone. The sow that is quiet and docile in temperament proves a good mother and is careful with her litter. These characteristics can, to some extent, be judged before the sow has been used. The ideal sow has ten to twelve welldeveloped, sound teats. Sows occasionally have "blind" teats that are rarely detected before farrowing. The number of sound teats is sometimes considered an indication of prolificacy in the sow. Prolificacy usually is a family characteristic, and it is wise 
to select a prospective brood sow from a large litter of robust pigs. The strongest pigs of a litter, most suitable for prospective sows, ustually nurse from the teats nearest to the front of the udder. The prospective brood sow may, therefore, be chosen before she is taken from her dam.

In selecting brood sows, the higliest possible standard of excellence should be retained, and all others should be marketed for pork.

A practice too common in the South is to raise hogs in the woods, without any special care as to breeding or feeding, or else raise them in a dry lot and feed nothing but corn. In the former case the hogs make little growth and make an inferior animal that is hard to sell at any price, while those raised in the dry lot are never healthy or thrifty; and though they take on flesh, it is at a cost that wipes out all profit. Hogs raised on corn alone, worth 70 cents a bushel, will cost the owner 10 cents a pound on foot when ready for the market.

Hogs can be raised for 2 to 3 cents, but only when raised on pastures supplemented by corn or by crops grown for them, as oats, peas, and soy beans. Hogs are strictly a grazing animal, and should always be provided with pastures of Bermuda and clovers for summer and the winter-growing crops of oats, barley, or rye for winter.

The small pigs should have a separate feeding pen or lot arranged so the larger hogs cannot get in. Hogs should be provided with plenty of shade in the summer and dry sleeping quarters in the winter and plenty of fresh water at all times, and should be inoculated against hog cholera and have access to the following mineral mixture:

Charcoal (bushels) ............... 1/2

Salt (pounds) ................... 4

Hardwood ashes (pounds) ............. 10

Slacked lime (pounds) ............... 4

CLARENDON DAVIS.

Open a savings account, drawing four per cent interest, compounded semiannually. 


\section{THE SOUTHERN CROPPING SYSTEM}

O $R$, I should say, the lack of any proper system. Farming in the South is behind that of the North mainly because of the total lack of systematic farming and rotation, and no improvement can ever be made so long as men parcel out their land in little pieces for tenant croppers to grow cotton, without any idea of farm development and soil improvement.

A real tenant system-a plan by which real farmers can take a farm and, instead of running it down, build it up-has been devised and put into successful practice for over thirty years in Eastern Maryland. It is founded on the remark of the man who started it: "I do not want a man on a farm of mine who cannot make money there for himself while making the farm better every year." This man started with the idea that farming, as a joint enterprise between owner and tenant, could be made profitable to both. He bought a farm, with comfortable buildings and barns, and made a contract with a farmer to take it and manage it on shares. The landlord furnished the farm and buildings and kept them in repair. He furnished the fencing material, and the tenant built the fences. He furnished the paint and whitewash for the buildings, and the tenant applied them. The tenant must have a reputation as an intelligent farmer and must own stock enough for the farm. He must farm in a regular rotation as laid down in the contract, and all the hay and fodder and straw belong to him so long as he feeds them to his stock. He pays no rent for the stock except the manure. If a man has been on a farm five years and the farm shows no improvement, he is apt to be moved; but so long as he farms according to contract, he is certain to stay right there. This man bought farm after farm from the rentals of the preceding ones, until at the time of his death he had nearly 25,000 acres of land in fifty-six farms, all fitted with dwellings of comfortable class and with tenants making money, while the landlord was paying taxes on a million dollars'. worth of real estate, all made at farming. There are men living on these farms who have been there for over thirty years, and some have handed down the farms to their sons. who are farming on the same contract. Others have bought fine farms for themselves and have a good bank balance, and the lands

Page 55 
of the estate have steadily improved. By this fair system other men in Maryland have become millionaires, and the lands have been improved; and there are men of standing and influence in their county affairs who live on these rented farms and prefer it to owning one. There is no better opportunity in the South for men of means than the establishment of just such a system; but it means fitting the farms with dwellings, and not cabins, and equipping them so that men with means for farming can be induced to take them.

These millionaire landowners of Maryland are the plainest sort of business men and perfectly accessible. There is a story told of Captain Andrew Woodall, who owned more than a million dollars' worth of farms in Kent and Cecil Connties. He had an office on the wharf at Georgetown. One day an exquisitely dressed young man, with a shiny buggy, went there with the intention of renting a farm. He saw a rather "seedy-looking" man on the porch, and said: "Will you hold my horse a while?" "Certainly," said the man; and he stepped down and took charge of the horse. The young man went into the office and met the clerk and asked him if Captain Woodall was in. "No," said the clerk. "When will he be in?" "That depends on how long you keep him holding your horse." That fellow did not get a farm, for Captain Woodall knew a farmer at sight.

Renting farms on a fixed contract with men able to farm and giving the tenant a fair show has made more than one millionaire in Maryland, and the same sensible system would make millionaires and wealthy tenants all over the South. I knew a man who had been prominent in his county, had been a State Senator, and had means invested in various enterprises, who lived all his life on a rented farm, and said that he could make more money than by owning and farming it, while the investment in the farm gave the millionaire owner a clear income of five per cent on his investment. or better than government bonds. When a landowner gets in the wheat crop alone over 100,000 bushels in rent, it is easy to see that he can buy more farms. W. F. MASSEY,

Associate Editor of Progressive Farmer. 


\section{STATEMENT OF THE CONDITION OF THE HUNTSVILLE BANK AND TRUST CO. HUNTSVILLE, ALABAMA}

AT THE CLOSE OF BUSINESS, JANUARY 2, 1913

\section{RESOÜRCES}

Loans and discounts $\ldots \ldots \ldots \ldots \ldots \ldots$

Overdrafts ......................

Stocks and bonds $\ldots \ldots \ldots \ldots \ldots \ldots$.

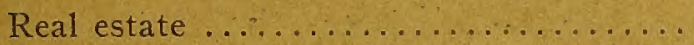

Furniture and fixtures ................

Due from other banks ............ \$130,825 91

Currency ..................... 21,049,00

Gold .................... $7,475,00$

Silver, nickels, and pennies ........ 9,617 62

Cash items and exch'ge for clearing house 15,538 78-184,506 31

Total ..................... $\$ \frac{\$ 84,806.35}{}$

\section{LIABILITIES}

Capital stock

$\$ 150,00000$

Suiplus and undivided profits ..........

Individual deposits $\$ 477 ; 93047$

Certificates of deposit 85,87201

Due to other banks $5,495.88$

Unpaid dividends $4,18500-573,48336$

Total
$\$ 546,919.78$

91850

28,20000

15,75000

8,51176

495- We solicit Accounts of Banks, Corporations, Firms, and Individuals. We are now making a study of the needs of Farmers and in the future will give SPECIAL ATTENTION to FARMERS' ACCOUNTS: LET THIS BE YOUR BANK. 


\section{OFFICERS}

Clarendon Davis, President

Lawrence Cooper, Vice President

E. T. Terry, Vice President

W. R. Hutton, Cashier

M. B. Merts, Assistant Cashier

\section{DIRECTORS}

C. L. Nolen W. I. Wellman Lawrence Cooper A. M. Booth
E. T. Terry Clarendon Davis R. E. Smith
C. C. Anderson

J. D. Hutton J. M. Shoffner W. R. Hutton 